Historic, Archive Document

Do not assume content reflects current scientific knowledge, policies, or practices. 
a SDII

, 656

stat $15 \operatorname{lng}$

Unlted States
Department of
Agriculture

Forest Service

Southern Region

Uis

General Report R8-GR 6

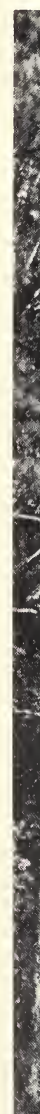

\section{Crossett}

\section{Demonstration} Forest Guide

By James B. Baker and Larry M. Bishop

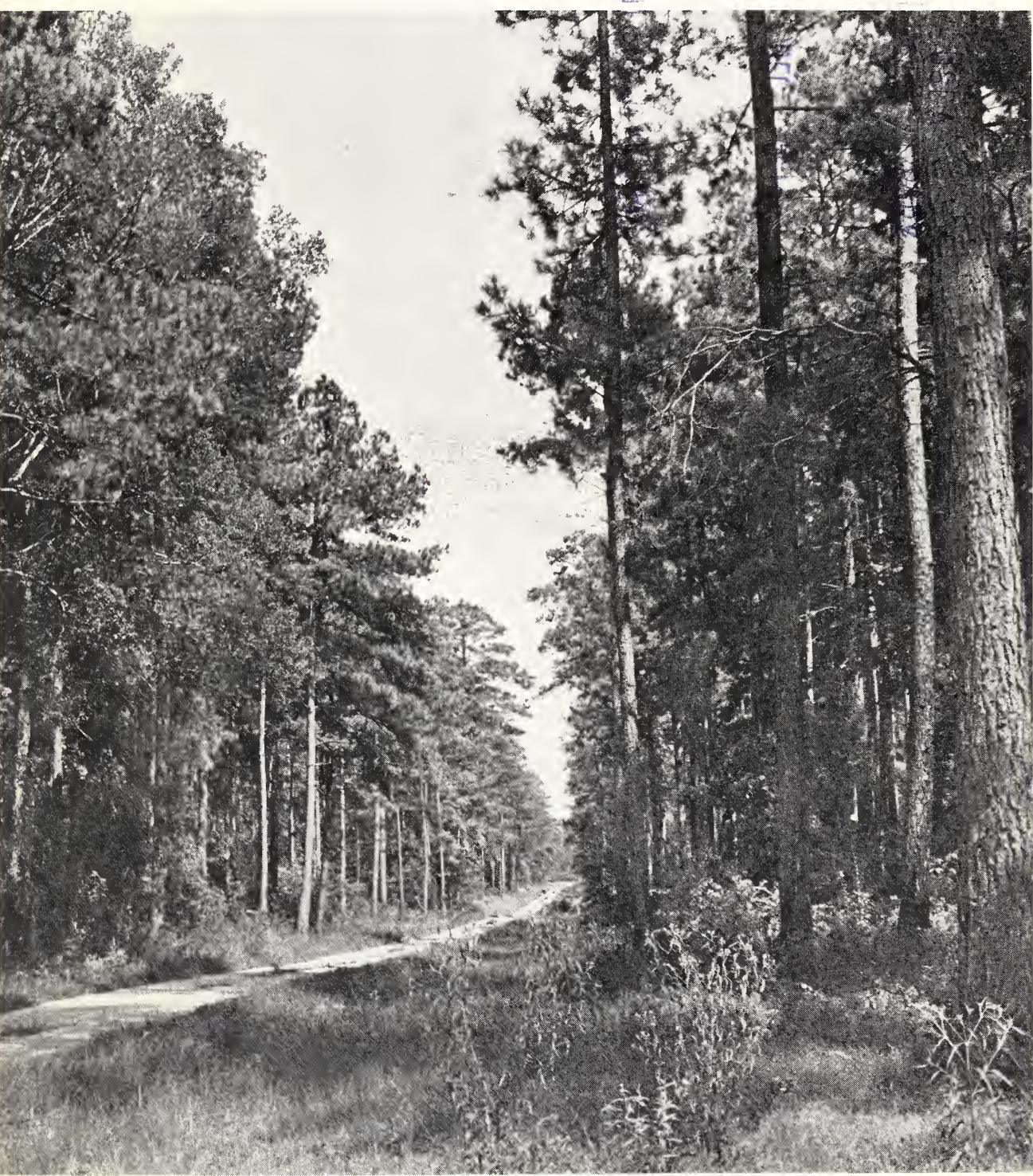





\title{
CROSSETT DEMONSTRATION FOREST GUIDE
}

\author{
by \\ James B. Baker, Project Leader \\ Southern Forest Experiment Station \\ Monticello, AR \\ and \\ Larry M. Bishop, Pine Silviculture Specialist \\ Southern Region \\ Atlanta, GA \\ USDA Forest Service
}

TO BE UTILIZED IN CONJUNCTION WITH

THE

CROSSETT EXPERIMENTAL AND DEMONSTRATION FOREST CROSSETT, AR 



\section{CONTENTS}

Page

PREFACE .....................

\section{A BRIEF HISTORY OF FORESTRY IN THE AREA ........ I}

DEMONSTRATION AREAS ................. 7

Unmanaged vs. Managed Forest ................ 8

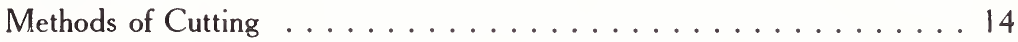

Stand Conversion Through Release Cutting . . . . . . . . . . . . 23

Farm Forestry Forties ................... 27

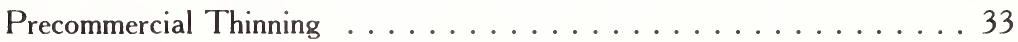

Sudden Sawlogs . . . . . . . . . . . . . . . . 37

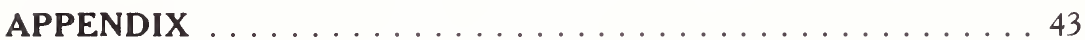

Crossett Experiment Forest--General Information ... . . . . . . . 43

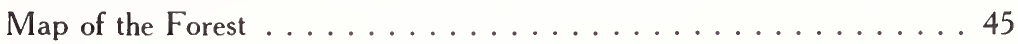

Forestry Terminology ....................... 46 


\section{PREFACE}

This guide has been prepared for use in conjunction with workshops and tours on the Crossett Experimental and Demonstration Forest. It contains detailed information to supplement oral presentations made at the various demonstration areas. It is also intended to serve as a future information source to recall specific management techniques and suggestions.

The Crossett Experimental Forest was deeded to the U.S. Forest Service in 1934 by the Crossett Lumber Company (now part of Georgia-Pacific Corporation). It is one of 14 experimental forests presently maintained by the Southern Forest Experiment Station, headquarted at New Orleans, LA. The Southern Station conducts research on forestry and related topics in a seven-State area. The research group responsible for the operation and maintenance of the Crossett Experimental Forest is stationed at two locations; the University of Arkansas campus at Monticello, AR, and the Crossett Experimental Forest located 7 miles south of Crossett, AR. Since its acquisition, this 1680-acre forest of mixed loblolly-shortleaf pine and hardwoods has been used for Federal forestry research and demonstration. Long considered a "Showplace for Forestry in the South", the forest has been visited during the past 50 years by over 10,000 landowners, foresters, and students.

The Monticello/Crossett research mission is to develop and evaluate low-cost silvicultural techniques and management alternatives suitable for natural stands on private nonindustrial timberlands in the mid-South. Research studies in these areas are underway on the Crossett Experimental Forest and at other locations throughout the South. Additional information on the studies and demonstrations at the Forest and other related projects can be obtained by contacting:

Project Leader

Southern Forest Experiment Station

U.A.M. Forest Resources Building

P.O. Box 3516

Monticello, AR 71655

(501) 367-3464 


\section{A BRIEF HISTORY OF FORESTRY IN THE AREA}

Toward the end of the nineteenth century, timber supplies in the Lake States were nearly exhausted, and many companies began moving their logging operations to the South - a land of virgin, yellow pine forests. In 1899, a young lumberman, E. W. "Cap" Gates, persuaded one of his relatives, C. W. Gates, and two Iowa investors, Dr. J. W. Watzek and E. S. Crossett, to purchase 47,000 acres of virgin timberland in southern Arkansas and northern Louisiana.

With the new landowners' blessings, "Cap" Gates supervised the construction of a sawmill and a small town nearby (fig. 1). Residences for employees, a church, a school, and a large company store were built, and Gates was appointed to serve as manager of the newly formed Crossett Lumber Company and the company-run town.

Meanwhile, boomtowns sprang up all over the South. Since most southern farmers viewed trees as something to be disposed of to make way for row crops, they usually welcomed the sawmillers with open arms. Production of lumber from the virgin pine stands continued to flourish across the South until about 1925, when it peaked and started declining as the timber was depleted. By the mid-1920's, many mills had moved on to the western States to harvest more virgin stands. Others that tried to hang on were forced to close when the Depression struck.

For the few companies that did not fold, the decision to start managing their forests was a gradual one - evolving only as a last resort. Up until about 1930, the Crossett Lumber Company had offered its cutover land for sale to local farmers. It had also tried raising cattle on an experimental basis, but this venture failed. After searching in vain for suitable land use options, the Crossett Company was probably receptive to suggestions when Professor H. H. Chapman of Yale University entered the picture. Professor Chapman, aided by his students, conducted inventories of some of the company's land during "spring camps" at Crossett and Urania, LA. Based on these inventories, he suggested the possibility that the company extend their railroad logging into some of the second-growth stands once the cutting of virgin timber had come to an end. Along with several other professors from Yale, Chapman also interested the company in hiring a trained forester, reserving pine seed trees, and establishing a fire protection system for its property.

These were novel ideas for the times. Prior to 1920, it was generally believed that the only kind of lumber worth anything for construction purposes was lumber cut from the slow-growing virgin forest. Second-growth lumber was considered practically worthless since much of it would shrink, warp, or twist, and it supposedly had very little strength. Besides, most logging before 1920 had been done by railroad, and this required a cut of logs of large enough size and volume to make the operation cost effective (fig. 2). Very few second-growth stands could meet these requirements.

Around 1933, A. E. Wackerman, a former Crossett Lumber Company forester who was subsequently employed by the U.S. Forest Service, suggested that some of 


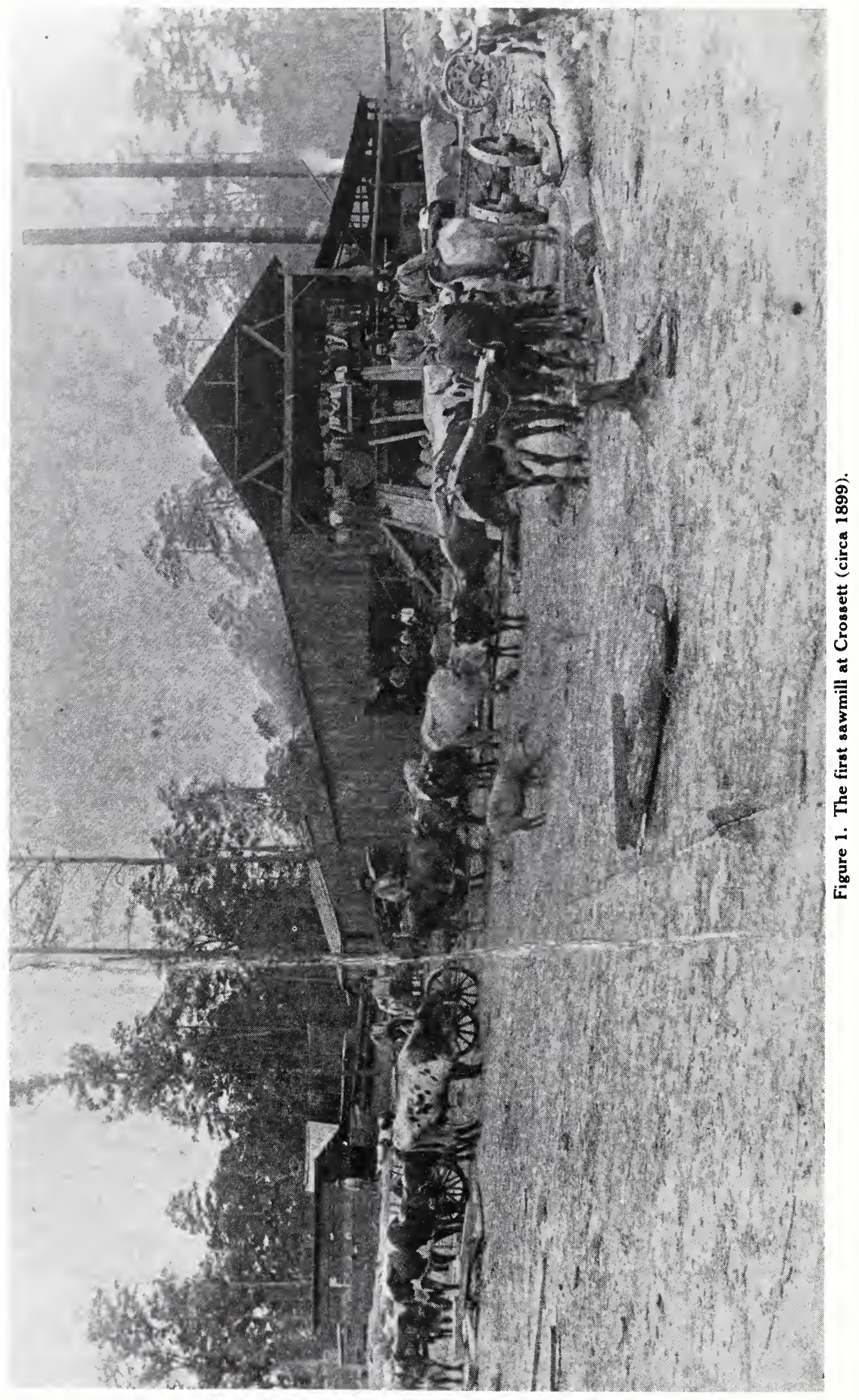




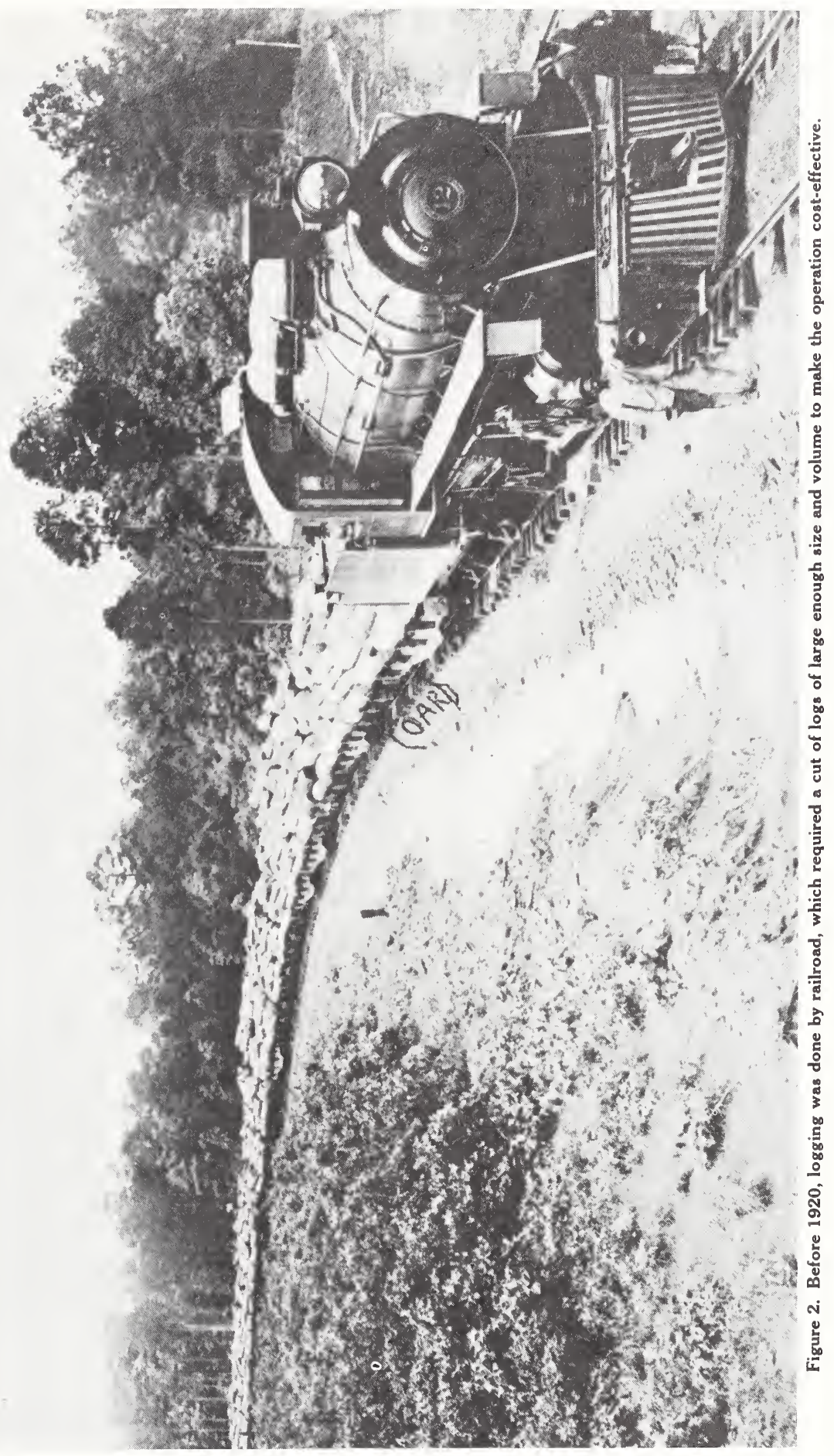


the problems of second-growth timber sales could be solved if the company mixed some of its old-growth timber with the second-growth timber. This way, the company could extend its fast dwindling supply of virgin timber.

In 1934, the Crossett Lumber Company made 1,680 acres of its cutover timberland available to the U.S. Forest Service to be used as a research center for studying ways of improving and rebuilding previously unmanaged second-growth stands. Russ Reynolds, a recent graduate of the Michigan School of Forestry, was selected from the staff of the Southern Forest Experiment Station to serve as project leader of the new Crossett Experimental Forest and Research Center.

Results of research undertaken by Reynolds and others provided alternatives to the "cut-out and get-out" principles of the past. For example, one of the first studies found that second-growth pine and hardwood stands could be profitably cut using horses for logging and trucks for hauling logs to railroad landing points.

The research work Reynolds initiated at Crossett soon began to attract nationaland later, international- attention. Perhaps the most famous of the Crossett experiments was the "farm forestry forties". This long-term study showed that owners of small tracts of loblolly-shortleaf pine could profitably manage their forest land using uneven-aged or selection management. Under selection management, an uneven-aged stand was maintained, and mature trees were harvested singly or in small groups at intervals, permitting continuous establishment of natural seedlings. Another well known experiment, the oldest of its kind on record, was the "Sudden Sawlogs" study in which sawlogs with an average diameter of 16 inches were produced in just 30 years. This study showed that intensive forest management could significantly boost volume production in a much shorter time than previously envisioned. In the "Release Study", Crossett scientists pioneered research to control both small and large hardwoods on pine sites. With this and other studies, they established the fact that soil moisture, more than any other factor, limits tree growth in most loblolly-shortleaf pine stands. It was this finding, and others like it, that gave rise to much of the research on the control of understory vegetation. The Crossett Experimental Forest was also the location of one of the earliest large-scale genetics programs in the South.

Meanwhile, forestry history continues to be made at Crossett. In 1962, GeorgiaPacific Corporation purchased the Crossett Lumber Company, and now operates numerous plants in the area producing plywood, paper, particleboard, lumber, and chemicals. In addition, several other plants oriented to the wood products industry are located in the city. The forest products complex at Crossett is the largest in the United States (fig. 3).

Today, the Crossett Experimental Forest serves as an "outdoor classroom" for private landowners, university students, and visiting foresters seeking to learn more about small forest practices and uneven-aged management. The old research areas have been retained and new ones are being established as demonstration areas to illustrate proven research techniques for management of private nonindustrial forestlands. 


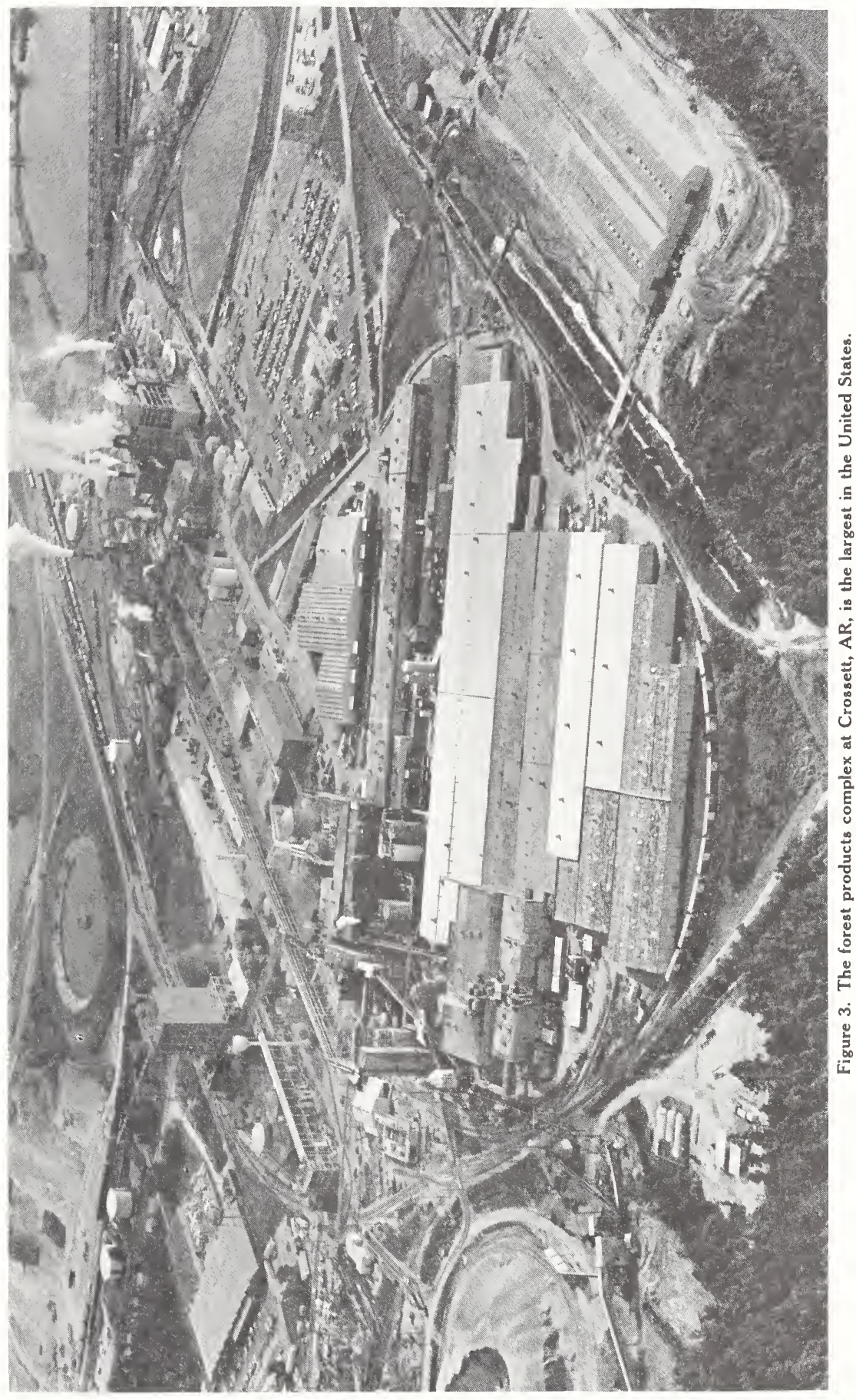



DEMONSTRATION AREAS 


\section{Unmanaged Vs. Managed Forest}

Many privately owned timber stands are not being managed for optimum timber production. In some cases, the land is held for recreation, wildlife habitat, scenic value, speculation, or other nontimber uses. For these landowners, timber production is a secondary goal at best. When most pine-hardwood stands are unmanaged, sawtimber production generally declines to about half of its potential or less.

One demonstration area in the Crossett Experimental Forest provides a case history of the development of an unmanaged pine-hardwood stand on a good site (site index $=$ 90 feet for loblolly pine at 50 years) and allows comparison of growth and yield from unmanaged and managed stands.

\section{History}

In 1935, two 40-acre compartments were set aside as a "natural area" that would undergo no forest management. These compartments were selected as being representative of the conditions on the Experimental Forest. No management practices, excluding fire protection, have been undertaken since a 12-inch-diameter limit cut in 1915 (fig. 4). The compartments were inventoried in 1937, 1942, 1946, 1952, 1957, 1963, 1973, and 1983. All trees 3.5 inches in diameter at breast height (d.b.h.) and larger were measured and tallied by 1 -inch d.b.h. classes.

\section{Results}

A summary of stand development and growth in these compartments is presented in table 1. During a 46-year period, the number of pines has diminished considerably from 130 merchantable trees per acre in 1937 to only 45 in 1983. The number of hardwoods has increased during this time from 65 to 112 merchantable trees per acre. In 1937, 67 percent of the merchantable stand was pine, but only 29 percent was pine in 1983. However, pine volume has increased from 1,467 merchantable cubic feet (2,277 board feet sawlog volume) to 2,961 cubic feet, or 8,183 board feet. Hardwood volume increased from 665 merchantable cubic feet, or 1,036 board feet, to only 954 cubic feet, or 2,244 board feet.

During the 46-year inventory period (1937-1983), annual pine growth has averaged 32 cubic feet, or 120 board feet per acre, whereas hardwoods have grown only 6 cubic feet, or 26 board feet. Since 1952, pine growth has diminished to only 100 board feet per acre per year, and for the last 20 years, it has averaged slightly over 60 board feet per acre per year. These growth patterns for pine are typical for unmanaged stands. The southwide average growth for unmanaged pine stands is less than 200 board feet per acre per year.

A comparison can be made between growth and development of the unmanaged mixed pine-hardwood stand described and the adjacent managed pine stand (fig. 5). The two stands were similar in species composition in 1937; however, the pure pine stand had considerably lower pine stocking with only 46 merchantable pines per acre. The merchantable pines had 21 square feet of basal area, and 520 merchantable 


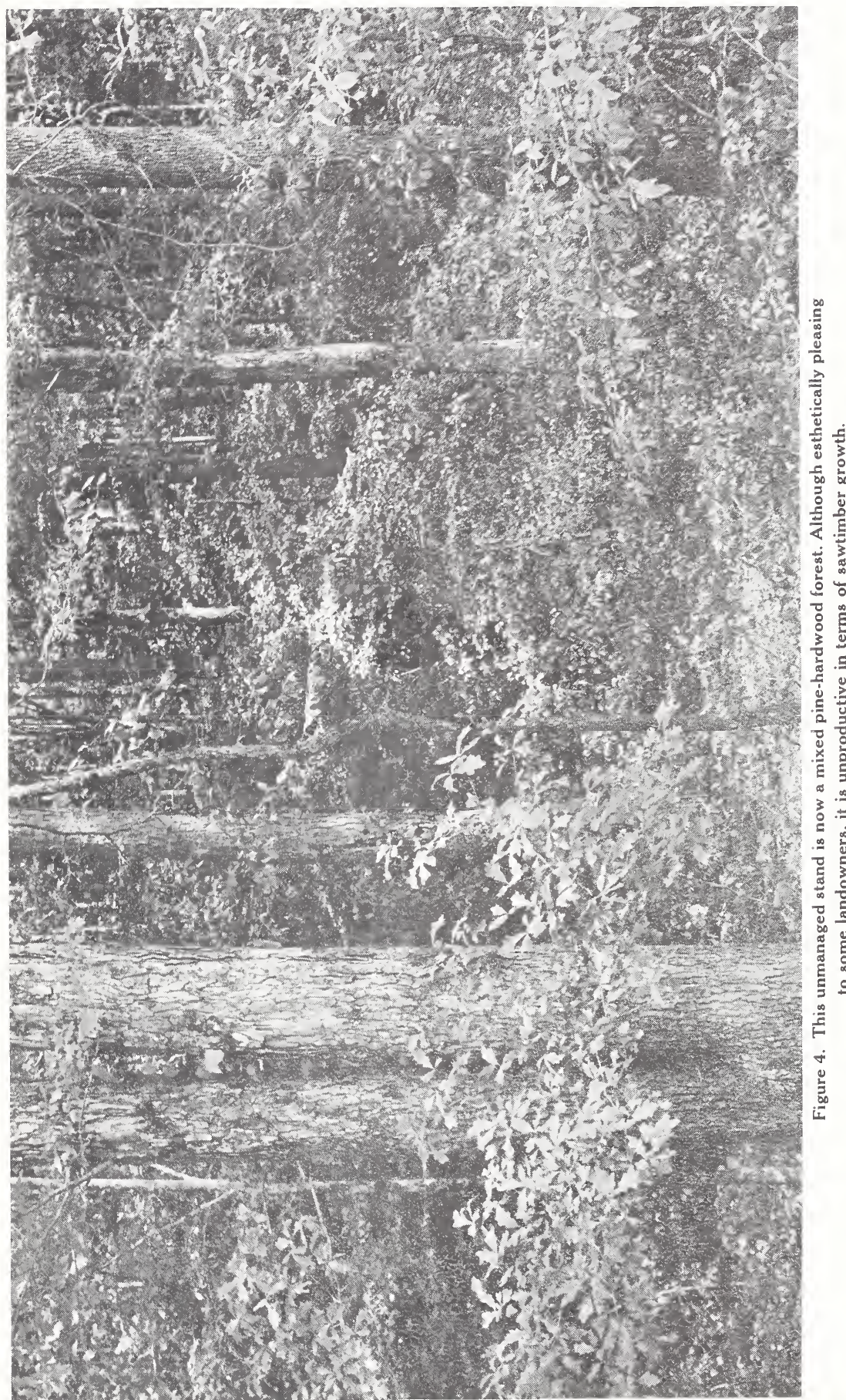




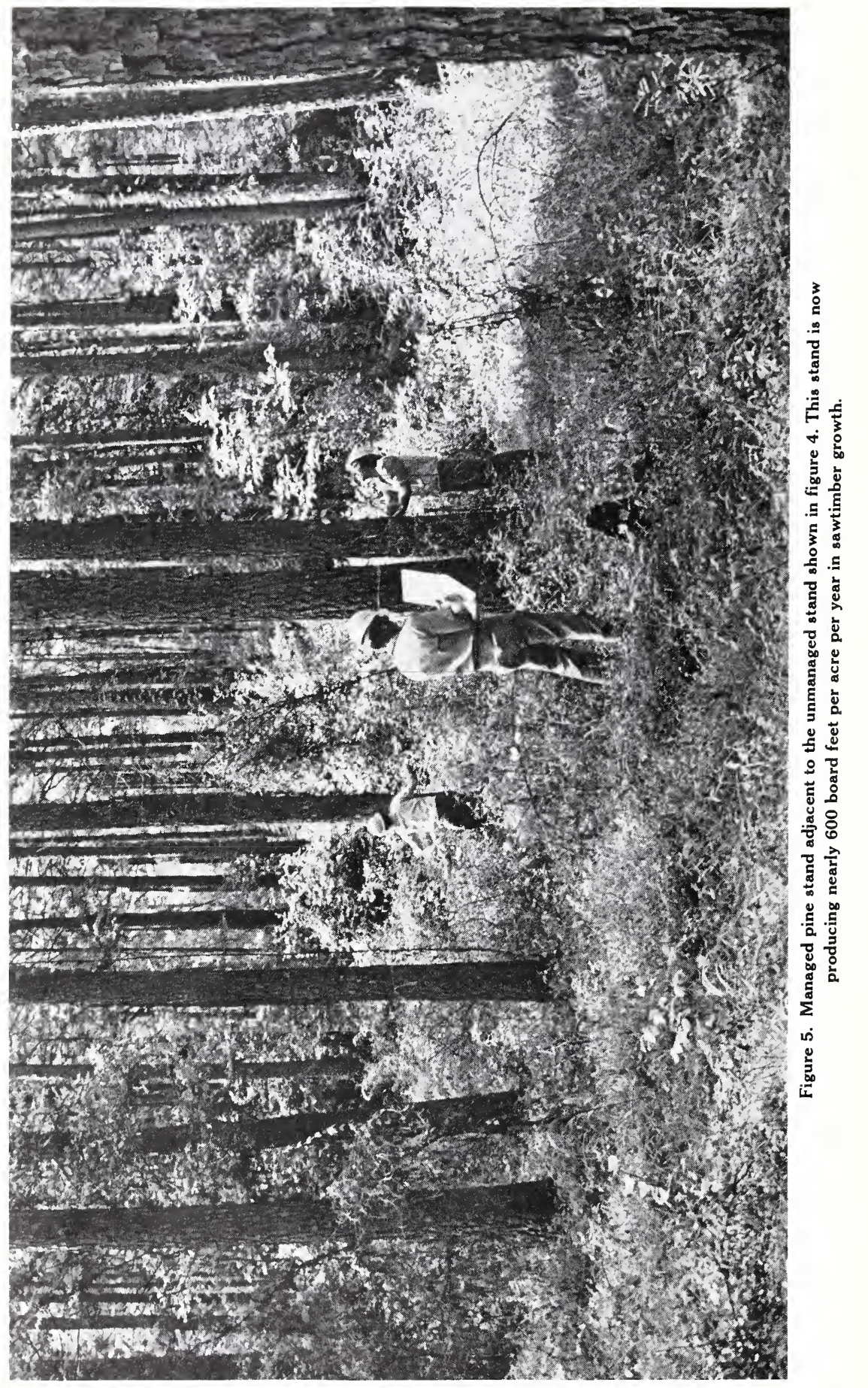


Table 1. Stand development and growth by species-groups

from 1915-83 (unmanaged stand)

\begin{tabular}{|c|c|c|c|c|c|c|c|c|c|}
\hline \multirow{3}{*}{$\begin{array}{l}\text { Species } \\
\text { group }\end{array}$} & \multirow[b]{3}{*}{ Year } & \multirow{2}{*}{\multicolumn{3}{|c|}{$\begin{array}{c}\text { Number of trees } \\
\text { per acre }\end{array}$}} & \multirow[b]{3}{*}{$\mathrm{BA} / \mathrm{A}$} & \multicolumn{2}{|c|}{$\begin{array}{c}\text { Standing volume } \\
\text { per acre }\end{array}$} & \multicolumn{2}{|c|}{$\begin{array}{c}\text { Annual growth } \\
\text { per acre }\end{array}$} \\
\hline & & & & & & \multirow{2}{*}{$\begin{array}{l}\text { Total } \\
\text { merch. }\end{array}$} & \multirow[b]{2}{*}{ Sawlog ${ }^{1}$} & \multirow{2}{*}{$\begin{array}{l}\text { Total } \\
\text { merch. }\end{array}$} & \multirow[b]{2}{*}{ Sawlog $^{1}$} \\
\hline & & $4^{\prime \prime}-11^{\prime \prime}$ & $12^{\prime \prime}+$ & Total & & & & & \\
\hline & & & & & Sq.ft. & Cu.ft. & Bd.ft. $^{2}$ & Cu.ft. & Bd.ft. ${ }^{2}$ \\
\hline \multirow[t]{10}{*}{ Pine } & 1915 & --- & $\cdots$ & --- & $\cdots$ & --- & 0 & --- & --. \\
\hline & 1937 & 106 & 24 & 130 & 57 & 1467 & 2277 & -.. & 104 \\
\hline & 1942 & 110 & 28 & 138 & 66 & 1763 & 3221 & 59 & 189 \\
\hline & 1946 & 81 & 33 & 114 & 69 & 1931 & 4087 & 42 & 216 \\
\hline & 1952 & 57 & 36 & 93 & 76 & 2320 & 5613 & 65 & 254 \\
\hline & 1957 & 47 & 39 & 86 & 81 & 2475 & 6174 & 31 & 112 \\
\hline & 1963 & 33 & 42 & 75 & 90 & 2622 & 6887 & 24 & 119 \\
\hline & 1973 & 20 & 43 & 63 & 94 & 2900 & 7799 & 28 & 91 \\
\hline & 1983 & 6 & 39 & 45 & 94 & 2961 & 8183 & 6 & 38 \\
\hline & & & & & & \multicolumn{2}{|c|}{ Average } & 32 & 120 \\
\hline \multirow[t]{9}{*}{ Hardwood } & 1937 & 48 & 17 & 65 & 38 & 665 & 1036 & --- & --- \\
\hline & 1942 & 47 & 16 & 63 & 37 & 649 & 934 & -3 & -20 \\
\hline & 1946 & 48 & 17 & 65 & 40 & 614 & 868 & -9 & -16 \\
\hline & 1952 & 69 & 19 & 88 & 43 & 751 & 1463 & 23 & 99 \\
\hline & 1957 & 62 & 18 & 80 & 40 & 680 & 1288 & -14 & -35 \\
\hline & 1963 & 56 & 18 & 74 & 41 & 714 & 1372 & 7 & 14 \\
\hline & 1973 & 62 & 19 & 81 & 42 & 845 & 1624 & 13 & 25 \\
\hline & 1983 & 100 & 12 & 112 & 52 & 954 & 2244 & 11 & 62 \\
\hline & & & & & & \multicolumn{2}{|c|}{ Average } & 6 & 26 \\
\hline
\end{tabular}

${ }^{1}$ Calculated by multiplying sawlog cubic-foot volume by 3.5 .

${ }^{2}$ All board-foot volumes are in Doyle scale.

cubic feet, or 1,409 board feet (table 2). The stand was placed under selection management in 1937 using a 6-year cutting cycle. At that time, all overstory and midstory hardwoods were removed. Since then, understory hardwood brush has been controlled with chemicals periodically.

Growth and development of the managed stand are summarized in table 2. From 1937 to 1981 , volume increased from 520 merchantable cubic feet, or 1,409 board feet, per acre to 3,350 cubic feet, or 14,109 board feet. During this period, an additional 1,425 cubic feet, or 6,429 board feet, per acre were harvested in five cyclic cuts. Thus, over the 44-year management period (1937-81), total production for the managed stand has been 4,255 cubic feet, or 19,129 board feet. The managed stand has averaged 97 cubic feet growth per acre per year, or 435 board feet, a 200-percent growth increase in cubic feet (or a 260-percent increase in board feet) over the unmanaged stand.

Even more dramatic is a comparison of present and potential timber production on the two areas. As of 1983, the unmanaged stand has produced 5,906 board feet of pine and 1,208 board feet of hardwood sawlogs. In comparison, 19,129 board feet of pine was produced in the managed stand through 1981. Another important comparison can be made between the present growth rate of only 38 board feet per acre per year in the unmanaged stand and volume growth in the managed stand, which has now 
Table 2. Growth and development of a managed pine stand (1937-81)

\begin{tabular}{|c|c|c|c|c|c|c|c|c|}
\hline \multirow[b]{3}{*}{ Year } & & & & \multirow[b]{3}{*}{$B A A$} & \multicolumn{2}{|c|}{ Standing volume } & \multicolumn{2}{|c|}{ Annual growth } \\
\hline & \multicolumn{3}{|c|}{ Trees per acre } & & \multirow{2}{*}{$\begin{array}{l}\text { Total } \\
\text { merch. }\end{array}$} & \multirow[b]{2}{*}{ Sawlog } & \multirow{2}{*}{$\begin{array}{l}\text { Total } \\
\text { merch. }\end{array}$} & \multirow[b]{2}{*}{ Sawlog } \\
\hline & $4^{\prime \prime}-11^{\prime \prime}$ & $12^{\prime \prime}+$ & Total & & & & & \\
\hline & & & & Sq.ft. & Cu.ft. & Bd.ft. & Cu.ft. & Bd.ft. \\
\hline 1915 & $\cdots$ & --- & -- & --- & --- & 0 & --- & --- \\
\hline 1937 & 37 & 9 & 46 & 21 & 520 & 1,409 & --- & 64 \\
\hline 1942 & 44 & 13 & 57 & 28 & 766 & 2,154 & 49 & 149 \\
\hline 1948 & 47 & 15 & 62 & 33 & 1,077 & 3,048 & 68 & 405 \\
\hline 1954 & 134 & 20 & 154 & 54 & 1,328 & 4,366 & 59 & 404 \\
\hline 1960 & 210 & 24 & 244 & 84 & 1,935 & 5,194 & 148 & 278 \\
\hline 1966 & 174 & 31 & 205 & 95 & 2,367 & 6,715 & 147 & 398 \\
\hline 1978 & 44 & 60 & 104 & 106 & 3,175 & $12,408^{1}$ & 109 & 648 \\
\hline 1981 & 39 & 63 & 102 & 111 & 3,350 & $14,109^{1}$ & 58 & 567 \\
\hline \multicolumn{5}{|c|}{ Average } & & & 97 & 435 \\
\hline \multicolumn{5}{|c|}{ Total cut (1942-1966) } & 1,425 & 6,429 & & \\
\hline
\end{tabular}

${ }^{1}$ Such high stocking levels are not recommended and are the result of two missed cycle harvests in 1972 and 1978 (while the Experimental Forest was temporarily closed). Similar annual growth rates can be obtained with lower stocking levels; i.e., 7,000 to 8,000 board feet per acre.

increased to a rate of 600 board feet per acre per year. Based on an average stumpage value of $\$ 200$ per thousand board feet, this comparison shows that the managed stand is producing about $\$ 120$ worth of sawlogs per acre annually, whereas the unmanaged stand is producing only about $\$ 8$ worth of sawlogs!

\section{Conclusion}

The cost figures in the preceding paragraph illustrate an important concept-what economists refer to as "opportunity cost." Some landowners may choose not to manage their forests for a variety of reasons. These could include a lack of technical knowledge about forest management, or a strong preference for a mixed forest encompassing many hardwood trees and shrubs, or perhaps just a basic belief that there is something inherently sinister about cutting down trees. They may also believe that no costs are involved in letting their woodlots develop into something similar to a natural area, since they're doing nothing and thereby incurring no expenses. Whether they realize it or not, in effect, they're paying a considerable price for nonmanagement. Why? Because they forego income that could be gained through management of their timberland. This loss of potential income is their opportunity cost.

If a landowner managed a 40 -acre woodlot similar to the managed uneven-aged pine stand, assuming again a stumpage price of $\$ 200$ per thousand board feet for pine, it would yield $\$ 120$ worth of timber per acre every year. Of course, the $\$ 120$ is not all profit because of certain expenses associated with management and sale of timber (most are tax deductible). But even if the expenses are $\$ 50$ a year-and this is a high estimate $-\$ 70$ per acre remains as profit. Income from the 40 -acre woodlot would then be $\$ 2,800$ per year. Furthermore, in most cases, 60 percent of this income is tax free since it presently qualifies for capital gains benefits. 
On the other hand, consider the landowner who decides not to manage a 40 -acre woodlot, but lets it develop to resemble a natural area. This owner gets satisfaction from just walking through the woods, or hunting squirrels, or photographing birds and wildflowers. There is zero income from the woodlot because no timber is cut or sold. Once aware of the opportunity cost, the landowner may want to reconsider whether that much satisfaction $(\$ 2,800$ a year in this case) is obtained from the unmanaged forest.

Of course, this example illustrates two extremes. Most owners manage their land to some degree, and it is unlikely that anyone would sell timber from the same tract on an annual basis. However, too many owners do not manage their land to a degree that would provide them with optimum benefit. No matter what the owner wants from the land, whether it is timber, wildlife, esthetics, or a combination of these values, he or she should be aware of the opportunity cost. Unfortunately, few things are free. To have some of one thing, some of another usually has to be given up. Doing nothing can be very costly.

\section{References}

Utz, Keith A. Forestry as an investment in the South. Gen. Rep. SA-GR 20. Atlanta, GA: U.S. Department of Agriculture, Forest Service, Southeastern Area State and Private Forestry; 1981. 5 p. 


\section{Methods Of Cutting}

This study was initiated in 1942 to compare four reproduction cutting methods in the loblolly-shortleaf pine type characteristic of the mid-Gulf Coastal Plain. The cutting methods included selection, diameter-limit, seed-tree, and clearcutting. Seedtree and clearcutting produced even-aged stands, whereas selection and diameter-limit cutting promoted development of uneven-aged stands.

\section{Objectives}

The objectives of the study were to determine for each treatment:

(1) what difficulties would arise in assuring adequate pine reproduction

(2) what problems with low-quality hardwoods would be encountered

(3) what growth and yield could be produced

The purpose of the demonstration area is to compare and contrast four reproduction cutting techniques that might provide suitable pine reforestation and management alternatives for private nonindustrial landowners.

\section{Treatments}

Twelve 4.4-acre plots with 2.5-acre interior measurement plots were established and three replications of the following four treatments imposed:

- Clearcutting-All merchantable pines 5.6 inches d.b.h. and larger were harvested in 1942. The seed source was adjacent uncut stands. The regenerated stand was thinned to 80 square feet basal area in 1980 .

- Heavy seedtree-All merchantable pines 5.6 inches d.b.h. and larger were harvested in 1942 except for 15-20 dominant or codominant seed trees per acre that were harvested in 1958, 15 years after the initial cut. The regenerated stand was thinned to 80 square feet basal area in 1980 .

- Diameter-limit-All pine sawtimber 11.6 inches d.b.h. and larger was harvested in 1942. Subsequent harvests removed all pines 11.6 inches d.b.h. and larger in 1953, 1958, 1968, and 1980.

- Selection-Single trees or small groups of trees were harvested on a 5-year cutting cycle beginning in 1942. Harvest cuts were regulated by volume control. Selection cutting was done in 1942, 1947, 1952, 1962, 1967, and 1980.

As a means of hardwood competition control, all hardwoods 5.6 inches d.b.h. and larger on all plots were either cut or girdled in 1942. The clearcut plots also underwent prescribed burning in the spring of 1942 to reduce logging slash, prepare a seedbed, and control small hardwoods. In 1946, all remaining hardwoods 3.6 inches d.b.h. and larger were cut from all plots to release pine reproduction.

\section{Results}

Stand characteristics before/after treatment and establishment of reproduction-Before treatment, the study area averaged 176 pines per acre, 68 square feet of basal area, 1,696 cubic feet merchantable volume, or 3,485 board feet ${ }^{1}$ sawlog volume (fig. 6).

\footnotetext{
'All board-foot volumes are in Doyle scale.
} 


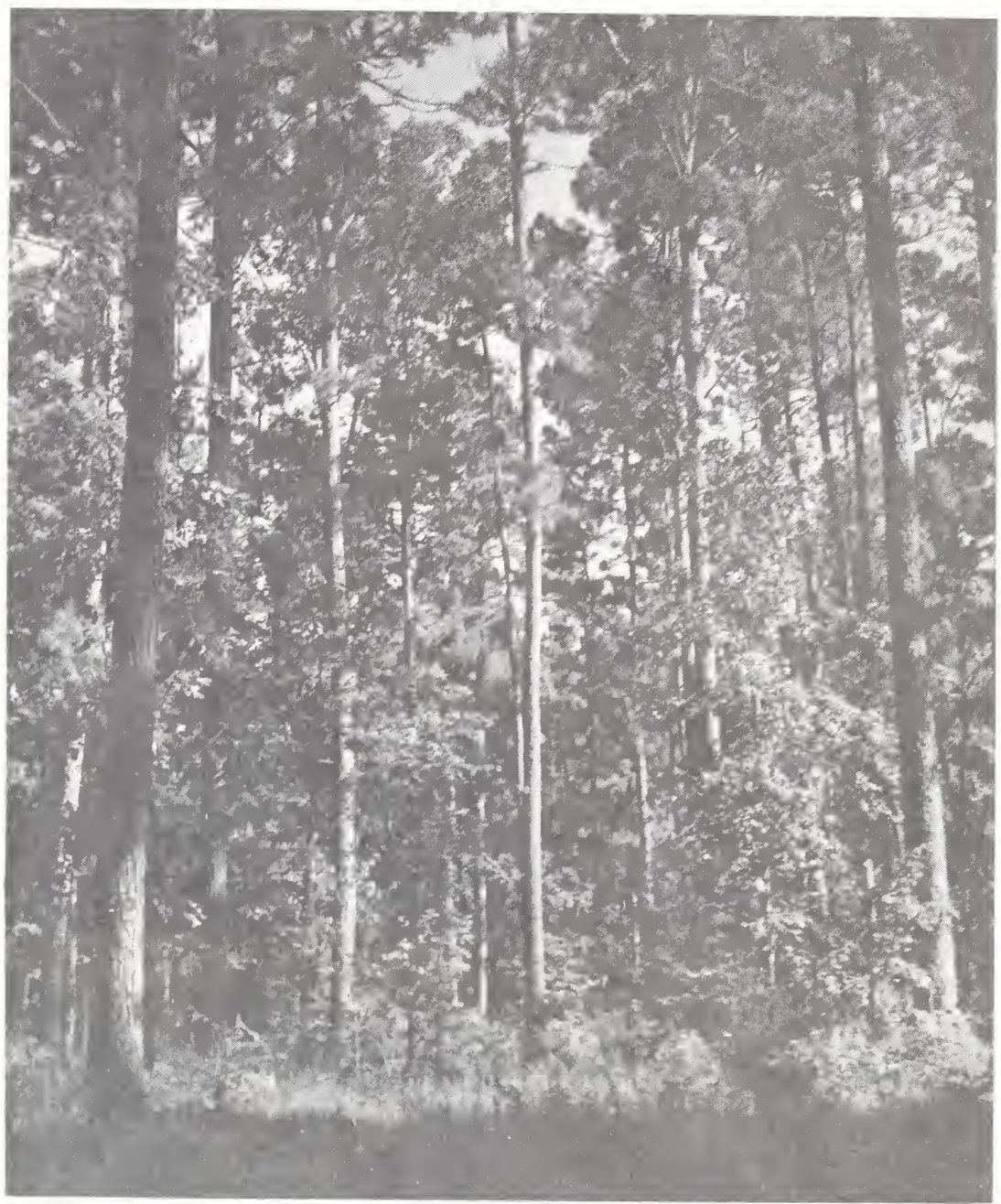

Figure 6. Second growth loblolly-shortleaf pine stand prior to treatments in 1942.

After treatment in 1942, the clearcut plots were reduced to 13 submerchantable ( 5.6 inches d.b.h. and smaller) trees per acre having 1 square foot basal area. Five years later, the clearcut plots averaged 2,470 pines 3.5 inches d.b.h. and smaller per acre (fig. 7A, B).

The seedtree cut reduced the pine stand to 15 to 20 seedtrees per acre that averaged 17 square feet basal area, and 477 cubic feet merchantable volume or 1,519 board feet sawlog volume (fig. 8A). After 5 years, pine reproduction on these plots averaged 3,845 stems per acre. Fifteen years after the reproduction cut and immediately before the overwood was removed (1958), pine reproduction averaged 1,900 stems per acre (fig. 8B). 


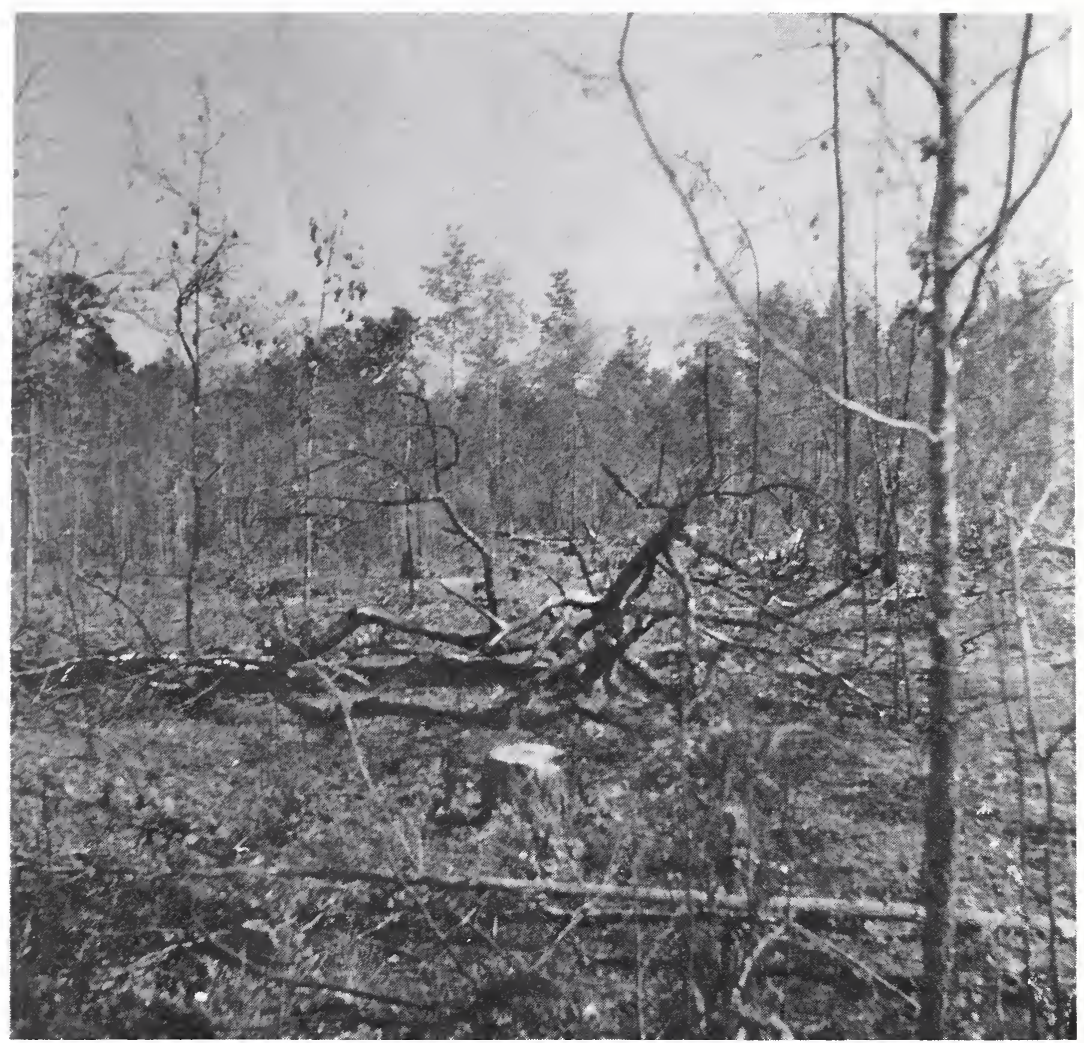

A

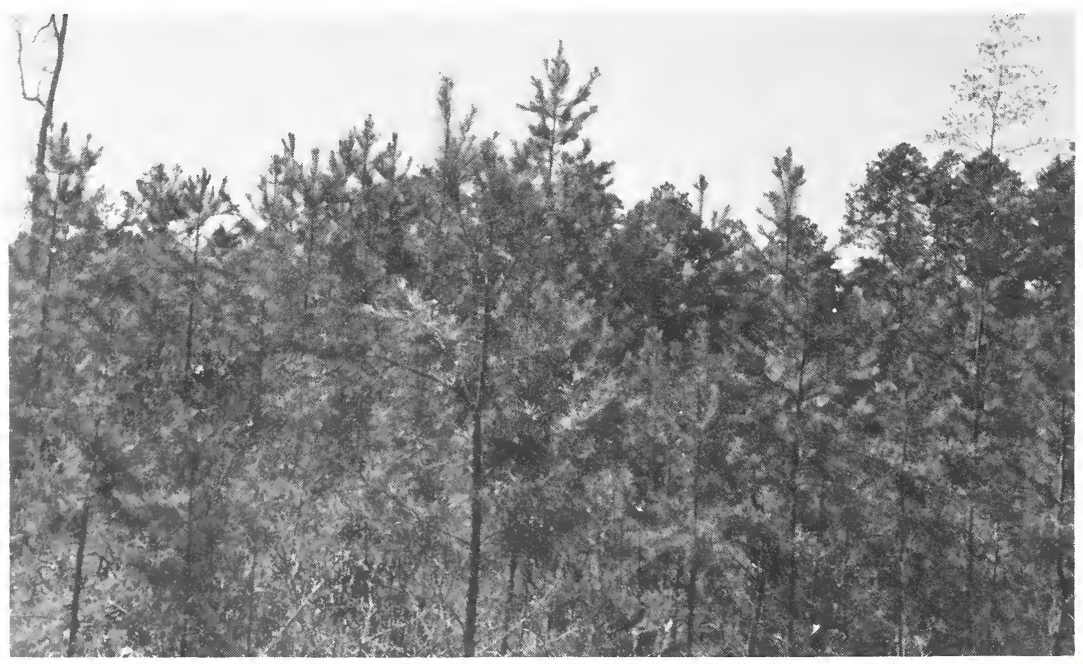

B

Figure 7. Clearcut treatment: A. Immediately after clearcutting in 1943; B. 5 years later (1948). 
Table 3. Volume production by treatments through 43 years (1985)

\begin{tabular}{llllcc}
\hline & \multicolumn{2}{c}{ Total production } & & \multicolumn{2}{c}{ Average annual production } \\
\cline { 2 - 3 } \cline { 5 - 6 } \multicolumn{1}{c}{ Treatment } & Cubic feet & Board feet & & Cubic feet & Board feet \\
\hline Clearcut & $4,026 \mathrm{~b}^{1}$ & $13,222 \mathrm{~b}$ & & $94 \mathrm{~b}$ & $307 \mathrm{~b}$ \\
Heavy seedtree & $4,838 \mathrm{a}$ & $16,057 \mathrm{a}$ & & $112 \mathrm{a}$ & $373 \mathrm{a}$ \\
Diameter-limit & $4,394 \mathrm{a}$ & $14,276 \mathrm{a}$ & & $102 \mathrm{a}$ & $332 \mathrm{a}$ \\
Selection & $3,562 \mathrm{~b}$ & $16,281 \mathrm{a}$ & & $83 \mathrm{~b}$ & $379 \mathrm{a}$ \\
\hline
\end{tabular}

1 Treatment means followed by the same letter are not significantly different $(0.05$ level).

Following the initial diameter-limit cut, the residual stand consisted of 93 trees per acre containing 25 square feet basal area and 420 cubic feet merchantable volume. All sawlog volume was removed (fig. 9). Five years later, pine reproduction totaled about 3,200 stems.

The initial selection harvest left the plots with 145 trees per acre, 56 square feet basal area, and 1,412 cubic feet merchantable volume or 2,823 board feet sawlog volume (fig. 10). Five years later, pine reproduction totaled about 2,900 stems per acre.

Total volume production-In 1985, standing tree volumes ranged from 641 cubic feet per acre, or 1,365 board feet, for the diameter-limit method to about 2,900 cubic feet, or 11,800 board feet, for the clearcut and seedtree methods (figs. 11 and 12). During the 43-year period, intermediate harvests removed $1,074,2,442,3,043$ and 4,173 cubic feet per acre of merchantable volume, or 1,431, 5,690, 12,100 and 12,911 board feet of sawlog volume from the clearcut, seedtree, selection, and diameter-limit plots respectively (figs. 11 and 12).

Total production or yield (present standing volume plus intermediate harvests minus initial volume after treatment) of merchantable cubic-foot volume during the 43 -year period ranged from 3,562 cubic feet for selection plots to 4,838 cubic feet for seedtree plots (table 3). Cubic yield for seedtree and diameter-limit cutting methods did not differ significantly, but averaged 22-percent higher than for the clearcutting and selection methods. Total board-foot volume production ranged from 13,222 board feet per acre with clearcutting to 16,281 board feet with selection management. Clearcutting resulted in 15 percent less board-foot volume yield for the study period than the average of the other three methods.

Had the two even-aged stands been thinned earlier, yields may have been different. Cubic yield may not have been affected much except for capturing mortality, but board-foot volume production could have been enhanced by distributing growth on fewer trees. However, no appreciable cubic-foot volume could have been harvested from the even-aged stands prior to 1963.

As the study progresses through a rotation, annual cubic-foot growth will probably decline, whereas annual board-foot growth will increase for the even-aged treatments. Annual growth for the diameter-limit and selection stands has basically stabilized at their current rates.

Development of the hardwood component-Prior to 1980, the last attempt to control hardwoods was in 1946, when all hardwood stems 3.6 inches in diameter and larger were cut. Development of the merchantable hardwood component progressed slowly for all treatments except the clearcut (table 4). There is a possible 


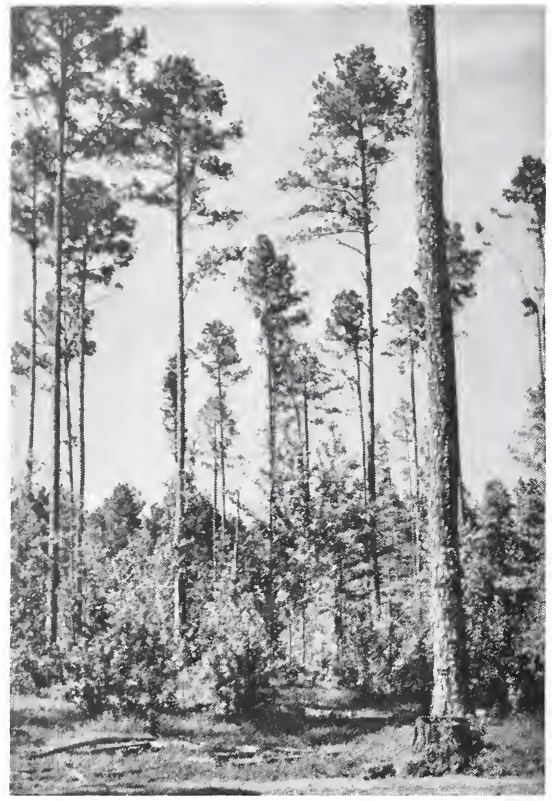

A

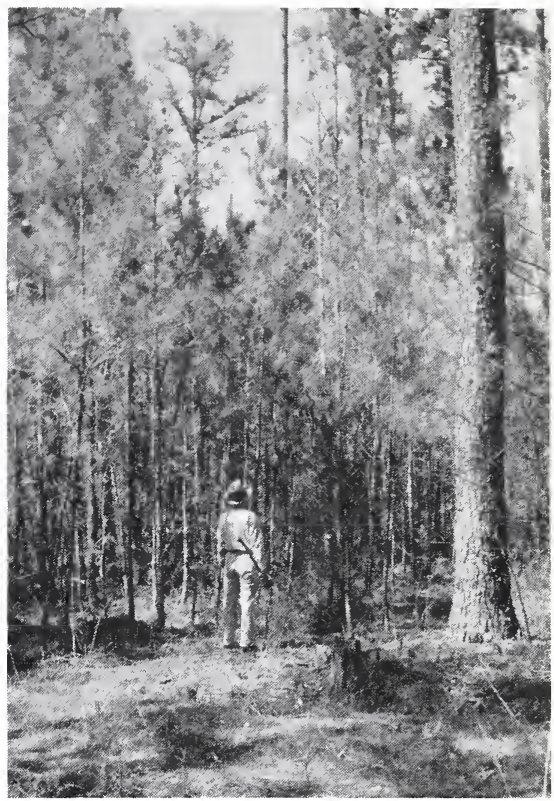

B

Figure 8. Seedtree treatment: A. Immediately after heavy seedtree cut in 1943;

B. 15 years later (1958).

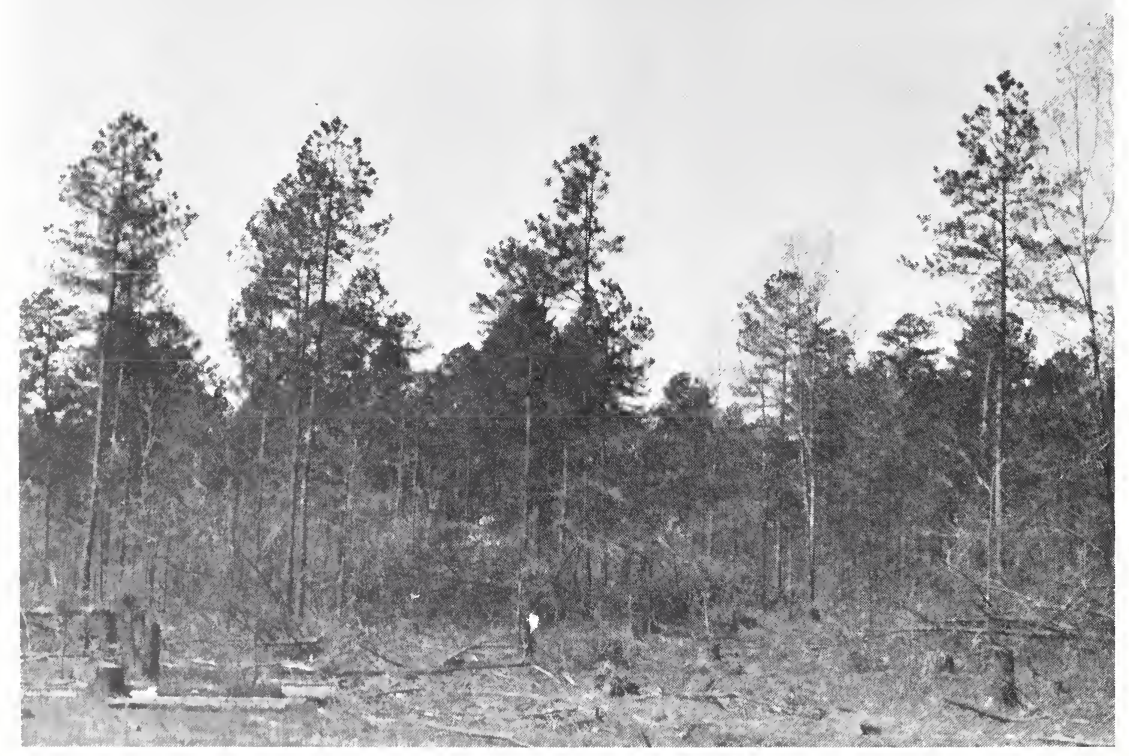

Figure 9. Diameter-limit treatment immediately after initial 12-inch diameter-limit cut in 1943. 


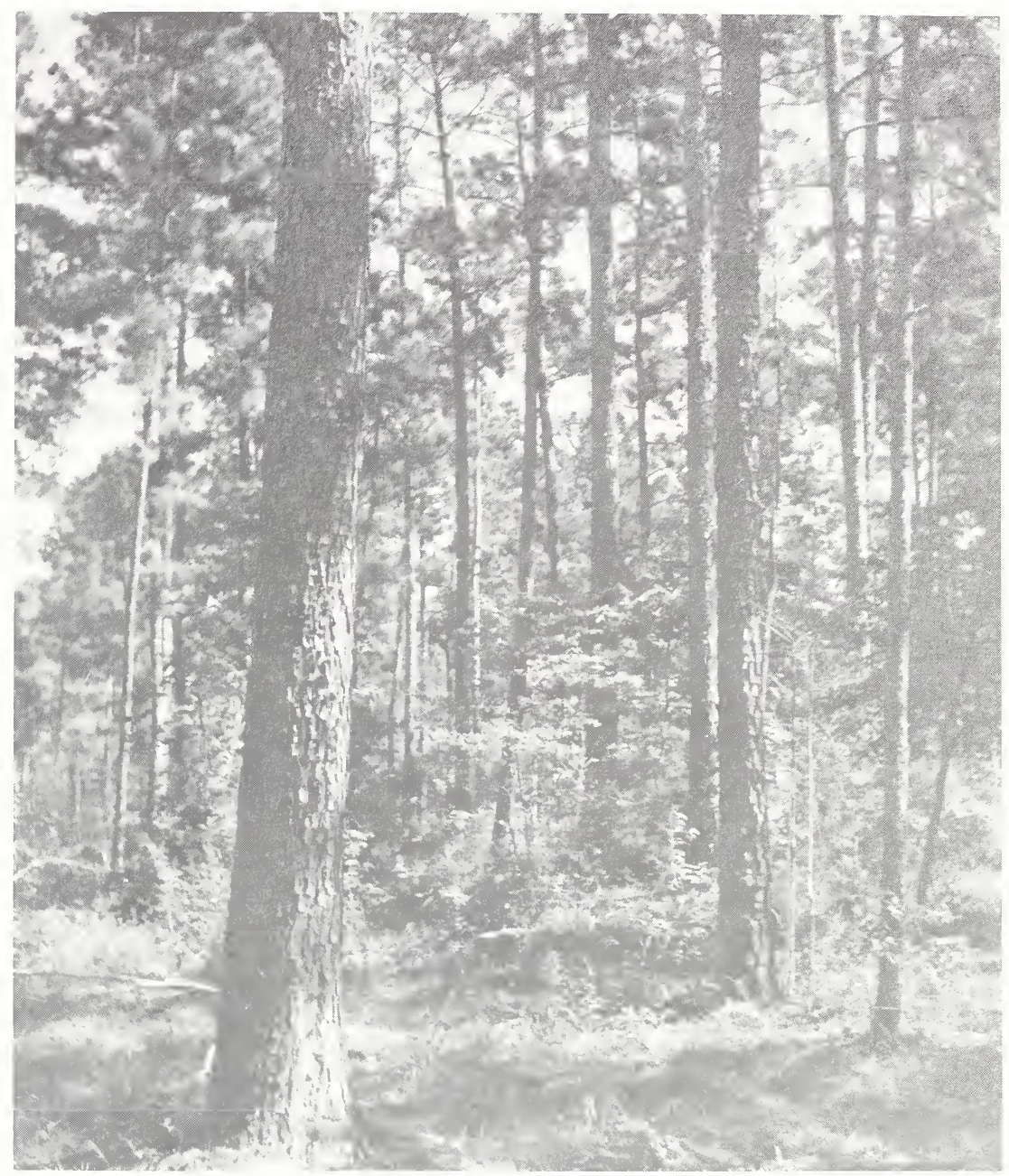

Figure 10. Selection treatment immediately after initial selection cut in 1943.

explanation for more merchantable hardwoods developing on the clearcut plots. Most southern hardwoods require complete overstory removal for optimum growth and development of regeneration. Thus, when the pine-hardwood overstory was removed on the clearcut plots, the treatment not only permitted seeding in of pine but also released advanced hardwood reproduction and promoted growth of stump and root sprouts. In the other treatments, a pine overstory was maintained that hindered growth and development of hardwoods.

It should be noted, however, that the clearcut plots had less submerchantable hardwood in 1979 than other treatments (table 4). This was possibly caused by the extra shading provided by the numerous midstory and overstory hardwoods present on 


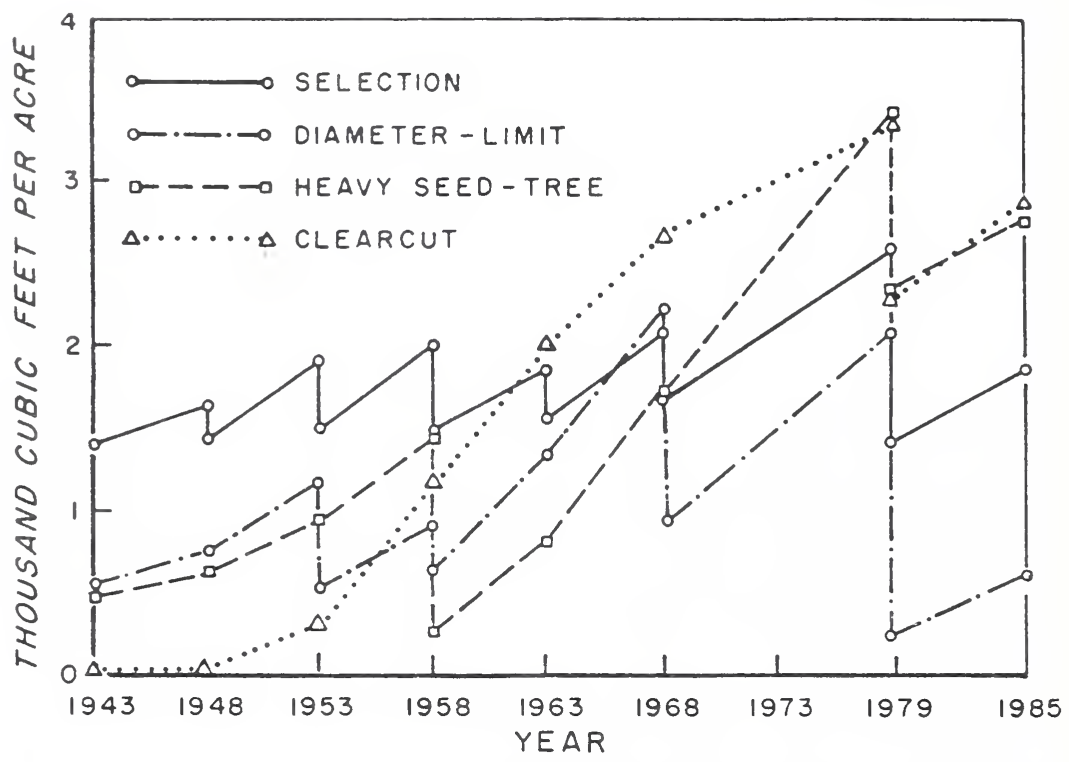

Figure 11. Average stand development in merchantable volume by cutting method.

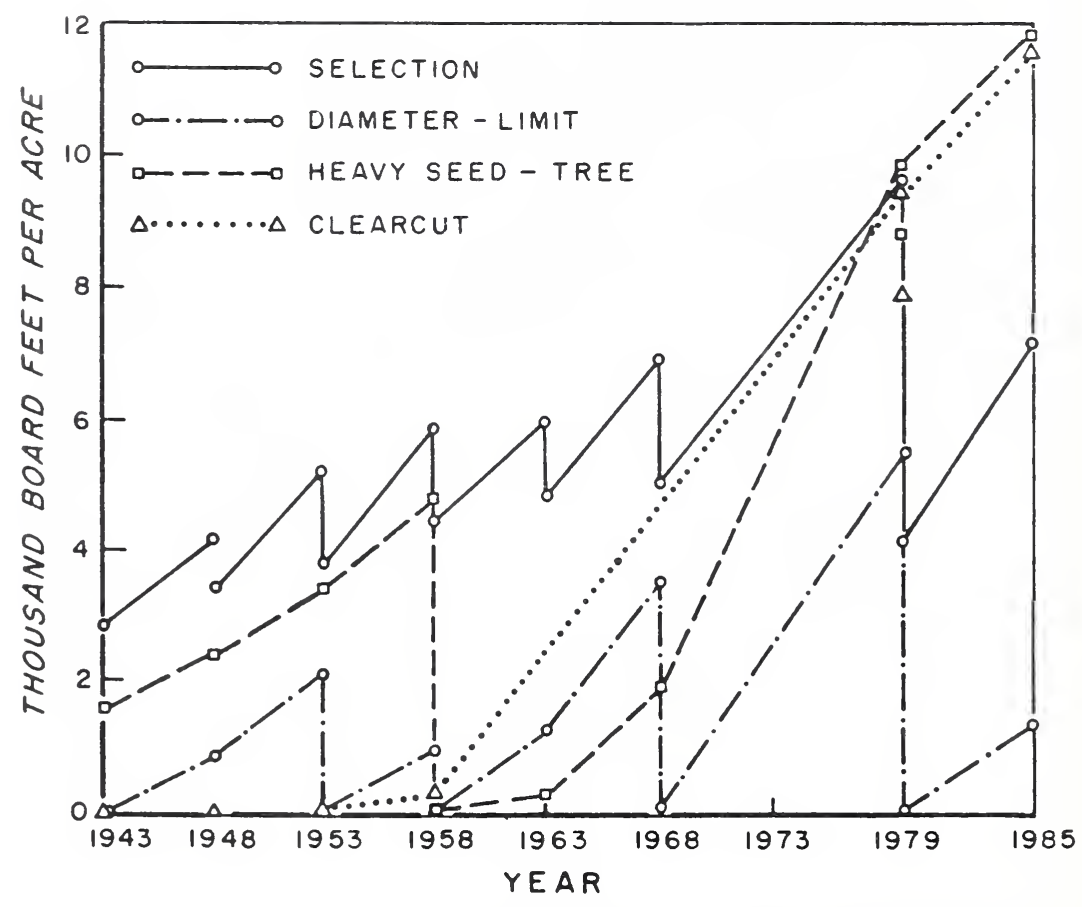

Figure 12. Average stand development in sawtimber volume by cutting method. 
the clearcut plots. In 1980, all hardwoods (1-inch groundline diameter and larger) on all plots were injected with herbicide.

Table 4. Hardwood component 36-years after treatment (1979)

\begin{tabular}{|c|c|c|c|c|c|c|c|}
\hline \multirow[b]{2}{*}{ Treatment } & \multicolumn{4}{|c|}{ Number of hardwood stems per acre } & \multicolumn{3}{|c|}{ Hardwood basal areas } \\
\hline & $3.6^{\prime \prime}$ & $3.6-9.5^{\prime \prime}$ & $9.5^{\prime \prime}$ & Total & $3.6-9.5^{\prime \prime}$ & $9.5^{\prime \prime}$ & Total \\
\hline & & & & & ----------. & are fee & ------ \\
\hline Clearcut & 1334 & 120 & 6 & 1460 & 21 & 3 & 24 \\
\hline Seedtree & 1811 & 35 & 1 & 1847 & 5 & 1 & 5 \\
\hline Diameter-limit & 2822 & 38 & 1 & 2861 & 6 & 1 & 6 \\
\hline Selection & 2117 & 44 & 0 & 2161 & 6 & 0 & 6 \\
\hline
\end{tabular}

\section{Summary and Conclusions}

All four reproduction cutting methods on a good site in south Arkansas provided adequate pine regeneration to establish or maintain well stocked stands. If overstory and midstory hardwoods are removed when management begins and the understory hardwood component is periodically controlled, then low-quality hardwoods should be no problem.

Through 43 years, the seedtree and diameter-limit methods have produced 22 percent more cubic-foot volume than clearcutting or the selection method. But clearcutting resulted in 15 percent less board-foot yield than the other three methods. Since many trees on the clearcut plots are just now reaching sawlog size, annual board-foot volume production within treatments will probably equalize as time goes on.

Even so, the four cutting methods have definite advantages depending upon management objectives. The two even-aged cutting methods are generally more practical and economically efficient for larger landholdings. Even-aged methods also allow management operations to be concentrated in time and space, permit management areas to be easily defined and treated, and require relatively simple technical management skill and supervision.

For many private nonindustrial owners, however, the even-aged methods have certain disadvantages that tend to make them less attractive. Some of these include: possible loss of the entire stand from fire, ice storms, insects, or disease, since the stand is homogeneous and remains so through time; and a long waiting period between the regeneration cut and the first intermediate cut. It also may be difficult to put a small forest into a regulated condition for even-aged management within a landowner's lifetime without sacrificing income or yields.

Uneven-aged stands are not so vulnerable to complete devastation by fire, biotic, or climatic agents; the uneven-aged method provides periodic income without interruption for stand regeneration and allows net income to be spread out over time, which may result in more favorable tax rates. In addition, a reserve of larger timber is available to take advantage of favorable market conditions and it satisfies esthetic demands at all times. With periodic harvests at frequent intervals, it is easier to time cash flows from harvest and cultural treatments so that debt financing can be minimized. This timing can be especially important for many private nonindustrial landowners with limited financial resources. 
On the other hand, uneven-aged management also has some disadvantages. It requires a higher level of technical skill and supervision to administer. With today's expensive logging equipment, loggers may be reluctant to harvest uneven-aged stands since many different size trees must be handled at the same time and larger areas covered to harvest a given volume. Logging damage to young trees being left in the stand is also difficult to prevent. These logging problems can sometimes result in reduced stumpage prices for the landowner.

A few other points about this study should be mentioned. First of all, it does not show one particular management treatment to be superior to another. The selection plots and the diameter-limit plots received intermediate harvests at 5 and 10 year intervals, respectively. The seedtree plots and the clearcut plots were not thinned until 1980 (stand age 38). As previously pointed out, yields would have been different had the clearcut and seedtree plots been thinned earlier. Also, research has shown that precommercial thinning, as well as seedtree removal at an early age, can significantly increase volume yields in natural even-aged loblolly stands.

Another point to be remembered is that the diameter-limit cut used in this study is very different from the typical diameter-limit cutting method used on many private nonindustrial forest lands. In this study, all trees 11.6 inches d.b.h. and larger, regardless of quality, were removed at 10-year intervals and hardwoods were controlled. A popular diameter-limit cutting method on many private forest lands is to cut trees to a smaller limit or cut only the high quality trees and then provide no hardwood control. It is not unusual to see timber sales where the minimum cut diameter is 8 inches at the stump, and often the timber is cut as soon as it is large enough to sell. Even though this is considered by some to be a "scientific" method of forest management, it is really nothing more than "high-grading" and this type of diameter-limit cutting cannot be considered a silvicultural method in any sense of the word.

So which method is best for private nonindustrial lands — even-aged or uneven-aged management? That depends on a variety of circumstances. No real basis exists for believing one is inherently better than the other. The choice requires careful consideration of many alternatives in light of the landowner's management objectives and needs. What may be perfectly suitable for one landowner may be totally unacceptable for another. And, therein lies the choice.

\section{References}

Baker, James B.; Murphy, Paul A. Growth and yield following four reproduction cutting methods in loblolly-shortleaf pine stands-a case study. Southern Journal of Applied Forestry, 6(2):66-74; 1982.

Balmer, W. E.; Utz, K. A.; Langdon, 0. G. Financial return from cultural work in natural loblolly pine stands. Southern Journal of Applied Forestry, 2(4): 111-117; 1978.

Brender, Ernst V. Silviculture of loblolly pine in the Georgia Piedmont. Report No.33. Macon, GA: Georgia Forest Research Council. 1973. 74 p.

Smith, D. M. The practice of silviculture. 7th ed. New York: John Wiley \& Sons Inc.; 1962: 467-514. 


\section{Stand Conversion Through Release Cutting}

Private, nonindustrial timber stands in the South are often mixtures of pines and low-value hardwoods. Research has shown that a substantial hardwood component reduces pine growth and potential income; therefore, it's to the landowner's advantage to convert these mixed stands to pure pine (on pine sites) to maximize timber production. Conversion can be accomplished either by total harvest cutting followed by natural or artificial regeneration, or by release of pine presently on the area. If sufficient pine stocking exists in the form of natural reproduction, suppressed saplings, or pulpwood, the most economical conversion method is usually through pine release.

The demonstration area described here shows how loblolly pine responds to release from low-grade, competing hardwoods, and demonstrates a practical management alternative for private nonindustrial landowners.

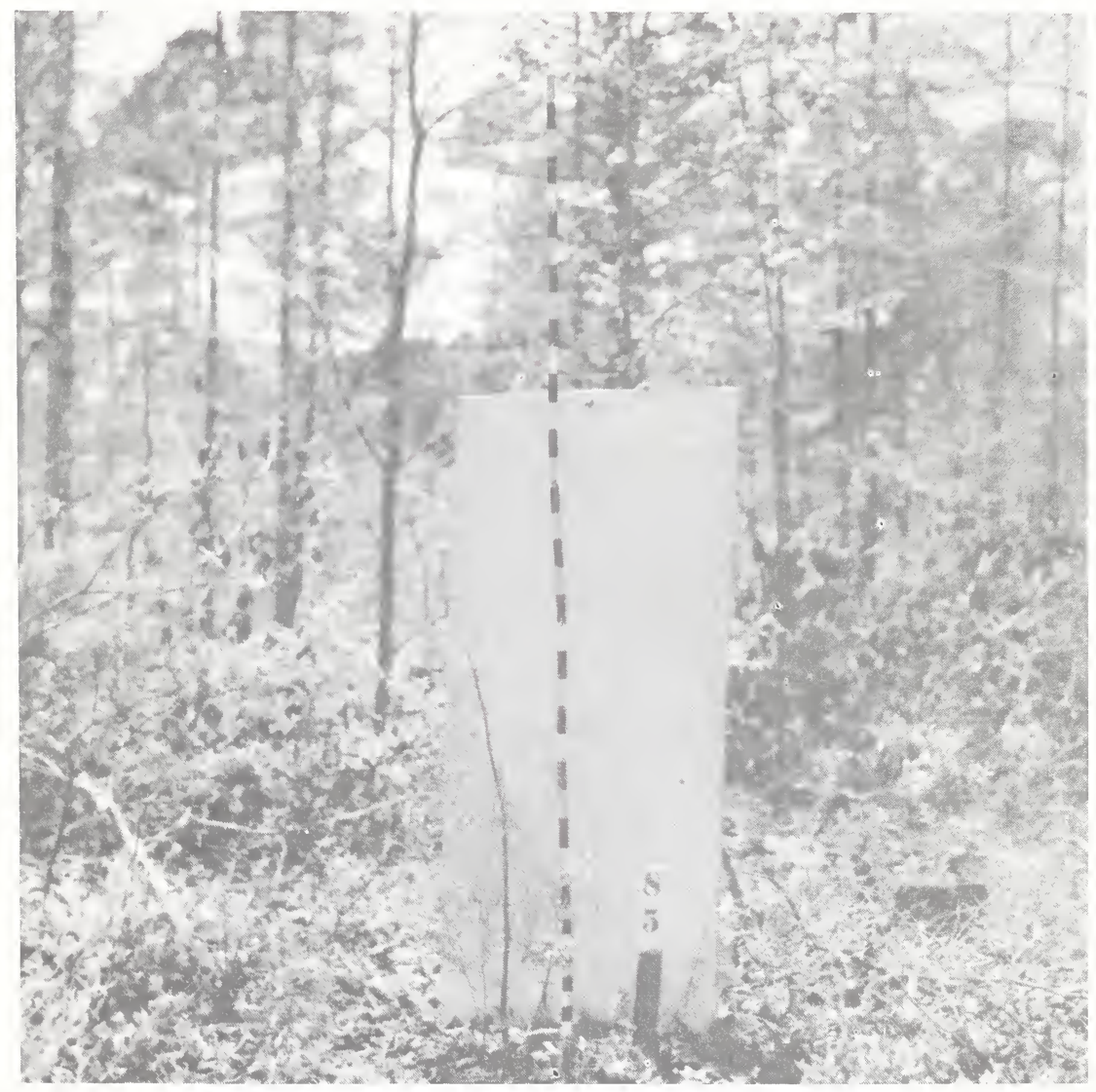

Figure 13. This 6-year-old loblolly pine (tree \#85) was released from overtopping hardwoods in the fall of 1940. (Photo made in spring of 1941.) 


\section{History and Treatments}

For several years preceding 1939, Russ Reynolds observed that numerous loblolly pine seedlings became established under dense, pine-hardwood overstories. However, most survived for only a few years and almost never developed into advanced reproduction.

In the spring of 1939, Reynolds installed a release cutting study in a typical area where low-grade hardwoods from 1 to 20 inches in diameter had taken over most of a good pine site. Although 1,200 suppressed pine seedlings per acre were present, they had little chance to get through the hardwood overstory.

Three different release treatments on a series of 1.25 -acre plots removed varying amounts of hardwood. Under Treatment 1, the competing hardwoods 6 inches d.b.h. and larger (overstory hardwoods) were removed; under Treatment 2 , the competing hardwoods 2 inches d.b.h. and larger (midstory + overstory hardwoods) were removed; whereas under Treatment 3 , the competing hardwoods 5 feet tall and larger (midstory + overstory + some understory hardwoods) were removed.

As another part of this study, 138 seedlings ranging from 0.3 to 7.1 feet tall were individually numbered. The purpose of numbering the seedlings was to obtain specific information on survival and growth as related to seedling size and degree of release. Survival, growth, and photo records have been maintained on some seedlings since 1939 (see figs. 13 and 14).

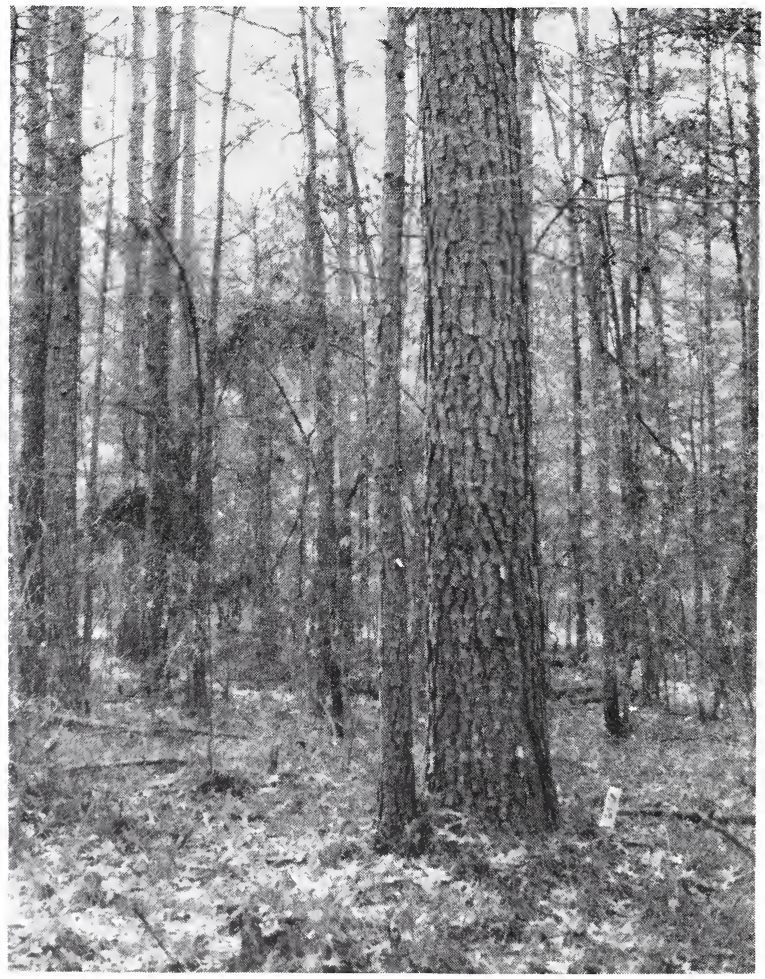

Figure 14. Tree \#85 42 years after release. 


\section{Results}

The following tabulation summarizes the influence of the treatments on the number and percentage of seedlings effectively released per acre. Plots initially had 1,200 seedlings per acre.

Treatment

\#1-Overstory hardwood removal

\#2-Midstory + overstory hardwood removal

\#3-Midstory + overstory + understory

hardwood removal
Seedlings effectively released per acre

(Number) (Percent)

571

48

695

Growth of the released pine seedlings during the next 10 years was excellent on areas under treatments \#2 and \#3, but unsatisfactory under treatment \#1. In treatments \#2 and \#3, released pine seedlings grew so rapidly that a thinning was made in 1949-just 10 years after treatment. Although it would have been at least 4 more years before sufficient volume could be removed from the plots in treatment \# 1 to make a thinning economically feasible, all plots were thinned to obtain a comparison for the returns. Treatment $\# 1$, which was not sufficiently intensive, resulted in a financial loss. In treatments \#2 and \#3, the returns from the thinning more than repaid the hardwood removal costs. The striking feature of this study is that an area almost completely dominated by low-value hardwoods was converted to a nice stand of pine at a small cost.

The following data illustrate the typical growth of pines released in treatments \#2 and \#3. Data are from tree \#85 (see figs. 13 and 14).

\begin{tabular}{|c|c|c|}
\hline $\begin{array}{c}\text { Years after } \\
\text { release } \\
\end{array}$ & Height & D.b.h. \\
\hline & (Feet) & (Inches) \\
\hline At release (1939) & 2.0 & --- \\
\hline 1 & 2.8 & --- \\
\hline 2 & 4.8 & 0.2 \\
\hline 10 & 26.0 & 4.0 \\
\hline 38 & 87.0 & 20.5 \\
\hline 45 & 92.0 & 21.9 \\
\hline
\end{tabular}


Other work on the Crossett Experimental Forest has demonstrated that pines suppressed by hardwoods for up to 35 years also respond well to release (see fig. 15). Private timberland owners having pine reproduction or even larger trees growing underneath low-value hardwoods can often release these trees and manage the existing pine stand instead of clearcutting, site preparing, and planting. The released pines will often grow into acceptable crop trees sooner (and at less cost to the owner) than plantation established pines.

\section{References}

Reynolds, R. R. Guide to the Crossett Experimental Forest. New Orleans, LA: U. S. Department of Agriculture, Forest Service, Southern Forest Experiment Station, Unnum. Pap.; 1951. 65 p.

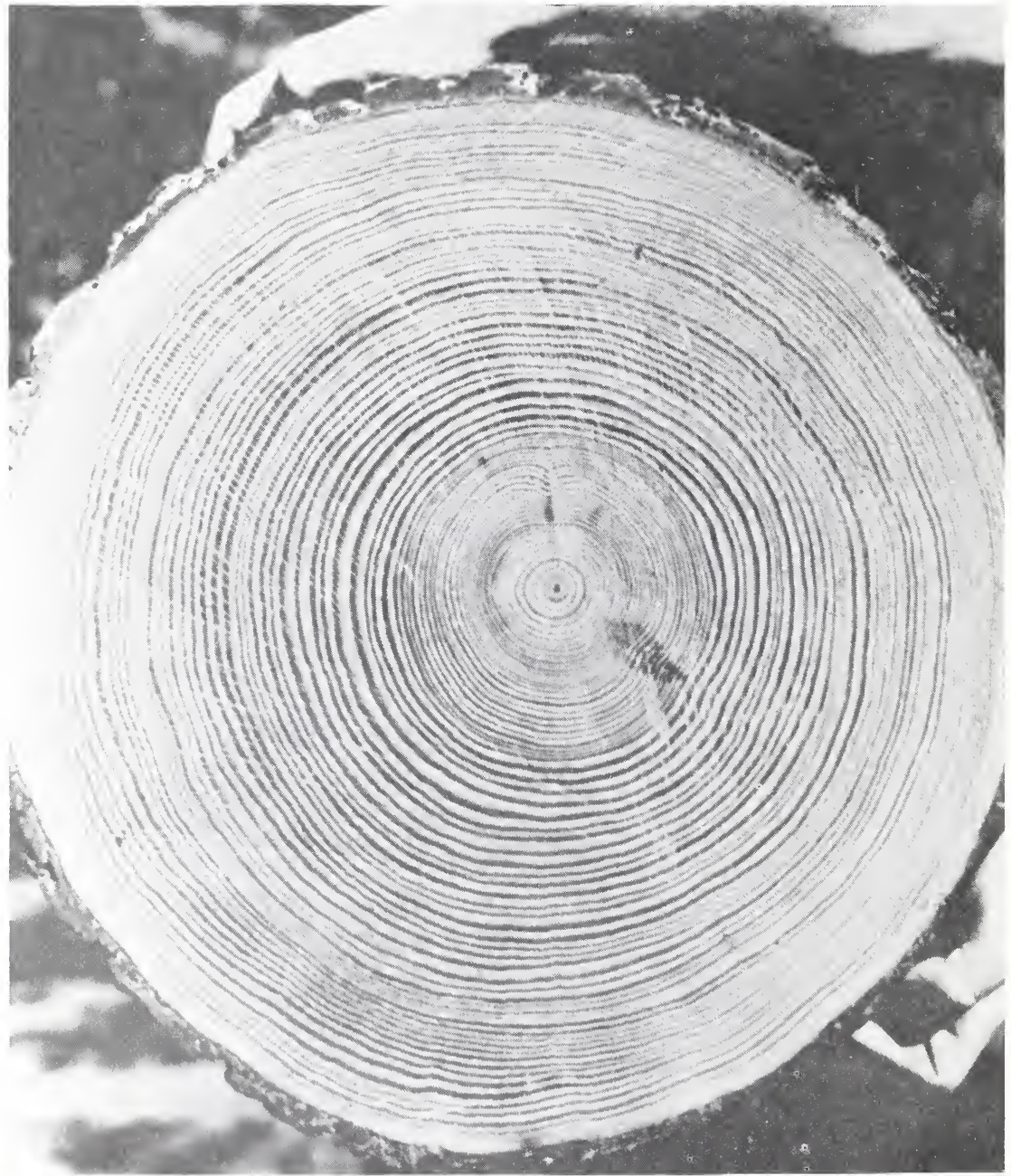

Figure 15. This cross-section illustrates the response of a 35-year-old loblolly pire to release treatment. At age 35, the tree was approximately 6 inches d.b.h.; 37 years after release, it was 24 inches d.b.h. 


\section{Farm Forestry Forties}

Timber stands on private nonindustrial properties are often left understocked in merchantable timber following intensive and frequent harvesting operations. As a result, foresters are usually confronted with the problem of making the land productive as quickly as possible at a low out-of-pocket cost to the landowner.

The demonstration discussed here illustrates a viable management alternative (selection management) that requires little capital investment but provides periodic income to the landowner while rehabilitating the stand. It also demonstrates the level of timber production that can be expected from exercising this management option on poorlystocked and well-stocked stands on good sites.

\section{History}

In the 1930's, approximately 20 percent of all the forest land in the Crossett area was owned by farmers. The average farm woodlot was about 28 acres in size. Thus, the amount of farm income depended to some degree on how well these owners managed their woodlands. To assist them in determining the best practices, the Crossett Research Center set up a farm woodland study as one of its first (and what later proved to be one of its most famous) experiments.

In 1937, two areas of approximately 40 acres each were established on the experimental forest. They were located in cutover and previously unmanaged secondgrowth loblolly-shortleaf pine stands. The objective was to determine whether the stands could be managed under the selection system to provide periodic harvests while improving overall stand structure and stocking.

One of the areas selected was poorly stocked with low quality pines. and much of it was covered with low-grade hardwoods-hence, it was named the "Poor Forty". Original stocking was 85 merchantable trees (3.6 inches d.b.h. and larger), 2,341 board feet of sawlog volume ${ }^{2}$, and 35 square feet of basal area per acre. It was typical of many run down farm forests in the area (fig. 16).

The second area was considered well stocked when the study was started. It was to be used to determine the production possible from farm woodlands once they had been built up to a desirable stocking level. Original stocking was 132 merchantable trees, 5,074 board feet sawlog volume, and 70 square feet of basal area per acre; therefore, it was named the "Good Forty".

Following removal or girdling of merchantable-size ( 5.6 inches d.b.h. and larger) hardwoods, annual harvests were begun on both "forties". The harvest cuts removed about half the annual growth on the Poor Forty to permit growing stock to build up rapidly. The harvests on the Good Forty removed slightly less than the annual growth to allow for a gradual increase in stocking. By 1951, 14 years later, the Poor Forty had reached adequate stocking and since that time, periodic harvests have about equalled growth. Competing hardwoods on both forties have been periodically controlled by removal, girdling, herbicides, or rotary mowing.

\footnotetext{
${ }^{2}$ See footnote 1 .
} 


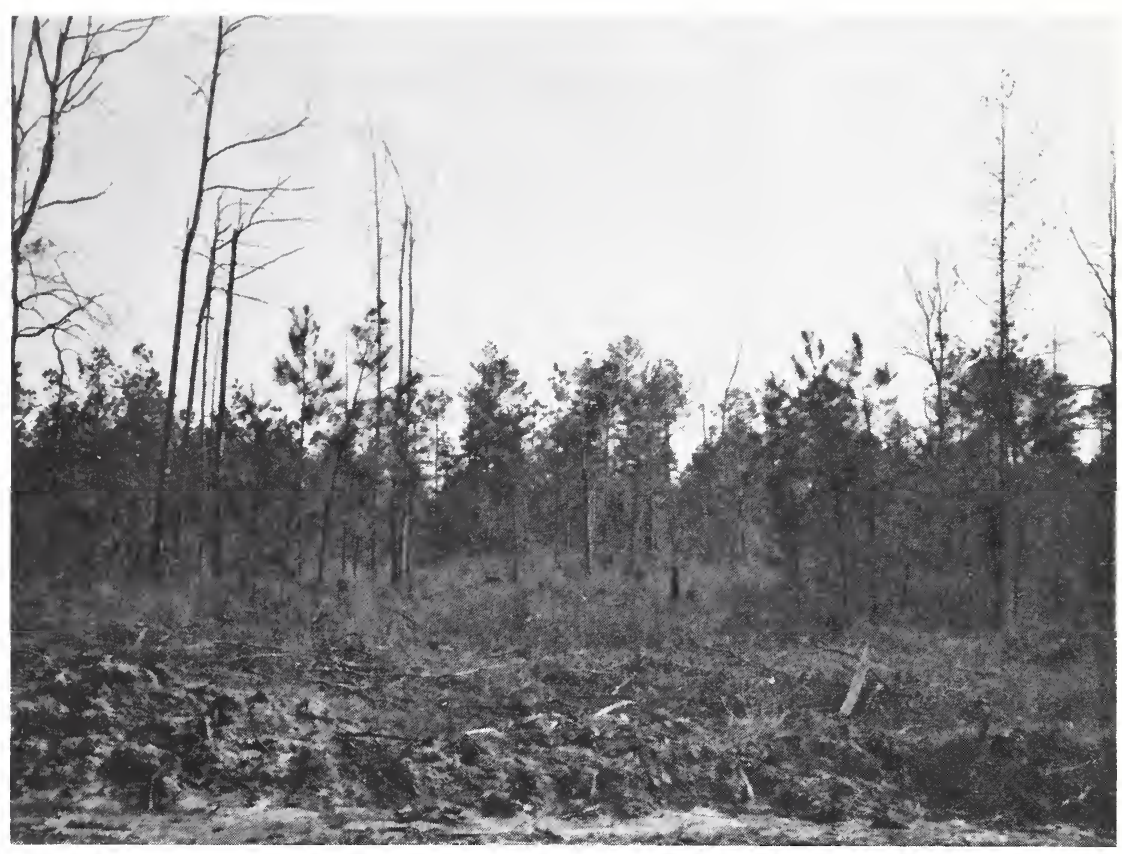

Figure 16. This stand is typical of the "Poor Forty" in 1937, having only 85 merchantable pines, 35 square feet of basal area, and 2,300 board feet of sawlog volume per acre.

\section{Results of Selection Management}

Poor Forty - Pine stocking on the Poor Forty improved substantially between 1937 and 1965 (table 5), increasing from 85 to 203 merchantable trees per acre and from 976 to 1,952 cubic feet (or from 2,341 to about 4,300 board feet) per acre. In 1978, the stand had 122 merchantable pines per acre, 84 square feet of basal area, and 2,393 cubic feet merchantable volume or 7,341 board feet sawlog volume. During the 41 years of selection management (1937-1978), the stand averaged 400 board feet per acre per year sawlog growth. For the 27-year period (1951-1978) since the stand became fully stocked, annual sawlog growth on the Poor Forty averaged 452 board feet per acre.

Even though the Poor Forty was lightly cut for the first 15 years of management, respectable quantities of timber products have been removed over the years. During the period 1937 to 1973, the area yielded a total of 451,640 board feet of sawlogs, 581 cords of pine and 186 cords of hardwood pulpwood, and 260 posts (table 6 and fig. 17).

Good Forty - During 41 years of selection management on the Good Forty, stand structure and stocking have fluctuated from around 100 to 120 trees per acre, with 70 square feet of basal area, 2,000 cubic feet of merchantable (or 7,500 board feet of sawlog) volume (table 5). Annual sawlog growth during this period has averaged 412 board feet per acre. 
Table 5. Number of pines, volume, and growth per acre on Poor and Good Forties

\begin{tabular}{|c|c|c|c|c|c|c|c|c|c|}
\hline \multirow[b]{3}{*}{ Year } & \multirow{2}{*}{\multicolumn{3}{|c|}{ Number of trees }} & \multirow{3}{*}{$\begin{array}{c}\text { Basal } \\
\text { area }\end{array}$} & \multicolumn{3}{|c|}{ Volume } & \multicolumn{2}{|c|}{ Annual growth } \\
\hline & & & & & $\begin{array}{l}\text { Total } \\
\text { merch. }\end{array}$ & & Sawlog & $\begin{array}{l}\text { Total } \\
\text { merch. }\end{array}$ & Sawlog \\
\hline & $4-12^{\prime \prime}$ & $12^{\prime \prime}+$ & Total & & $4^{\prime \prime}+$ & Cords $^{1}$ & $12^{\prime \prime}+$ & $4^{\prime \prime}+$ & $12^{\prime \prime}+$ \\
\hline & & & & Sq.ft. & Cu.ft. & & Bd.ft. & Cu.ft. & Bd.ft. \\
\hline
\end{tabular}

Poor Forty

$\begin{array}{rrrrrrrrrr}1937 & 68 & 17 & 85 & 35 & 976 & 12 & 2341 & \ldots & \cdots \\ 1951 & 105 & 25 & 130 & 54 & 1501 & 18 & 4188 & 91 & 291 \\ 1965 & 173 & 30 & 203 & 70 & 1952 & 23 & 4308 & 128 & 356 \\ 1978 & 70 & 52 & 122 & 84 & 2393 & 28 & 7341 & 132 & 556\end{array}$

\section{Good Forty}

\begin{tabular}{rrrrrrrrrr}
1937 & 102 & 30 & 132 & 70 & 1793 & 21 & 5074 & $\cdots$ & $\cdots$ \\
1951 & 46 & 36 & 82 & 73 & 1968 & 23 & 7350 & 79 & 392 \\
1965 & 112 & 31 & 143 & 71 & 1995 & 24 & 7220 & 86 & 274 \\
1978 & 69 & 39 & 108 & 84 & 2442 & 29 & 9265 & 107 & 475 \\
\hline
\end{tabular}

${ }^{1}$ Includes pulpwood-size stems and topwood from sawlog-size trees.

Table 6. Harvest from the Crossett Farm Forties, 1937-1973.

\begin{tabular}{|c|c|c|c|c|}
\hline Item & Sawlogs $^{1}$ & $\begin{array}{c}\text { Pine } \\
\text { pulpwood }\end{array}$ & $\begin{array}{l}\text { Hardwood } \\
\text { pulpwood }\end{array}$ & Posts \\
\hline & Bd. $\mathrm{ft}$. & \multicolumn{2}{|c|}{-...-..---Cords--..--..-- } & No. \\
\hline \multicolumn{5}{|c|}{ Poor Forty } \\
\hline \multicolumn{5}{|l|}{ Harvest } \\
\hline Total & 451,640 & 581 & 186 & 260 \\
\hline Per acre & 11,291 & 15 & 5 & 6.5 \\
\hline Per acre per year & 314 & 0.4 & 0.1 & 0.2 \\
\hline \multicolumn{5}{|c|}{ Good Forty } \\
\hline \multicolumn{5}{|l|}{ Harvest } \\
\hline Total & 500,840 & 569 & 228 & 418 \\
\hline Per acre & 12,521 & 14 & 6 & 10 \\
\hline Per acre per year & 348 & 0.4 & 0.2 & 0.3 \\
\hline
\end{tabular}

${ }^{1}$ Sawlog volumes are in Doyle scale.

Since initial stocking on the Good Forty was adequate, harvest cuts have almost equalled growth. Thus, from 1937 to 1973, 500,840 board feet of sawlogs, 569 cords of pine and 228 cords of hardwood pulpwood, and 418 posts have been harvested (table 6).

\section{Discussion and Conclusions}

When this study was established, it was assumed that farmers would manage and harvest their woodlots during the off-season when not tending their crops. It was found that, on the better stocked Good Forty, about 52 days per year were required to cut and deliver the annual harvest. This would have provided almost full-time off-season 


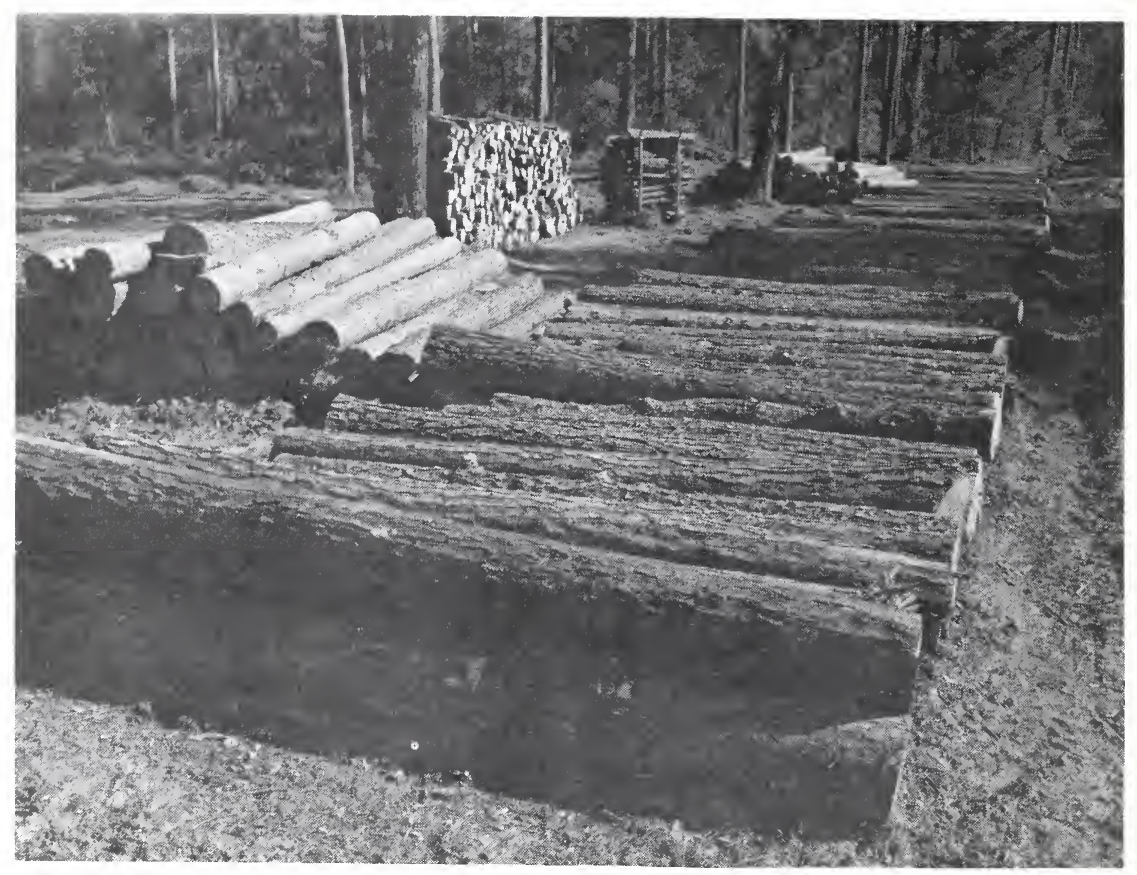

Figure 17. A typical annual harvest from the Poor Forty after stand rehabilitation. These products represent 1 year's growth of about 500 board feet per acre.

employment for most farmers. These research results also showed that imber could, indeed, be considered as much an annual crop as corn, potatoes, or cotton.

One might wonder why the Poor Forty now has a greater annual growth rate than the Good Forty. The answer is that, even though both woodlots have similar site indices, the Good Forty today has many trees in the larger diameter classes that are growing at a slower rate, whereas the Poor Forty generally has many smaller and more vigorous trees growing collectively at a faster rate. Some of the larger trees on the Good Forty are of such a size now that it is no longer profitable to retain them if the objective is to maximize financial returns. This factor illustrates an important point in forest management: just as timber can be harvested too soon, it can also be carried too long, and then financial returns will decline.

What kind of financial returns can a landowner expect from a fully stocked unevenaged stand such as the present Poor Forty? If we use the present volume procluction figures from table 5 , some predictions can be made. ${ }^{3}$ However, a few basic assumptions must be made first.

Let us assume we have a 40 -acre block of land similar to the Poor Forty (site index 90 ), and we want to cut it every 5 years. In making any financial analysis, we first

\footnotetext{
${ }^{3}$ Financial analyses and prediction of economic returns provided by Bennett Foster, Forest Economist, Southern Region, USDA Forest Service
} 
need to consider costs. In this example, let us assume a $\$ 3$ per acre per year management cost for routine timber cruises, fire prevention, etc. Also, let us assume that after each cut, every 5 years, we will have to pay $\$ 25$ per acre for certain cultural treatments such as injecting competing hardwoods, etc. The value of the land should not be considered since land, alone, has traditionally been a good investment. Also, land is often owned for reasons other than investment; therefore, timber will be considered a separate investment. Likewise, property taxes should not be considered because they are the cost of holding land - not growing timber. Property taxes still must be paid even if the land is not producing a crop. Another cost that should be considered is the value of the standing timber itself. A landowner does have the option of selling all standing timber at the beginning of the cutting cycle and investing the returns from the sale elsewhere; therefore, since growing stock is considered capital, it is the major cost of the investment.

According to table 5, the Poor Forty had 7,341 board feet per acre of standing sawtimber in 1978 and was producing an average of 556 board feet per acre annually. If we start our 5 year cutting cycle at this point, we need to harvest 2,780 board feet ( 556 board feet/year X 5 years). This leaves us with a residual standing volume of 4,561 board feet per acre $(7,341$ - 2,780). At a value of $\$ 200$ per thousand board feet, this residual growing stock volume represents a capital investment of $\$ 912$ per acre $(4,561$ board feet $X \$ 200$ per thousand board feet).

Now we need to consider the selling price. First, let us continue to assume a sawtimber selling price of $\$ 200$ per thousand board feet. Pulpwood volume production, costs, and selling price will not be considered since these will have only a minimal effect on the overall rate of return on the investment.

Let us also assume a 5 percent inflation rate. Historically, sawtimber prices have risen faster than the rate of inflation, and economists predict that these price trends will likely continue. Therefore, let us assume that the price of sawtimber will rise at a rate of 1.5 percent above the assumed rate of inflation. For example, stumpage prices will increase at the rate of 6.5 percent per year, if inflation increases at a rate of 5 percent per year.

Now that we have made these assumptions, we can predict our future costs, our future income, and the internal rate of return (IRR). Calculation of the IRR is a rather tedious and involved process that we will not go into here; however, the result of the calculations indicate 16.3 percent IRR $^{4}$.

Although 16.3 percent looks like a good rate of return, it looks even better when the tax benefits of forestry investments are considered. Income from a timber sale can, in most cases, qualify as a long-term capital gain. Under present Federal income tax

\footnotetext{
${ }^{4}$ If more conservative inflation rates are assumed, say 3 percent and 0 percent, the IRR's would be 14.1 and 10.9 percent, respectively. With no inflation and no stumpage price increase, the IRR drops to 9.2 percent.

If a more conservative sawtimber selling price $(\$ 100$ per thousand board feet, increasing at 1.5 percent above inflation) were assumed, the IRR's for inflation rates of 5, 3, and 0 percent would be 15.5 . 13.3, and 10.0 percent, respectively. The small difference between IRR's when stumpage rates are significantly different ( $\$ 100$ and $\$ 200$ per thousand) is explained by the fact that stumpage rates greatly influence both revenues (harvests) and costs (the value of residual volumes)
} 
laws, only 40 percent of the gain is taxable as ordinary income. The other 60 percent is tax free! Another advantage of forestry investments is that certain expenses associated with the growing and selling of timber can be deducted from Federal income tax as "operating expenses" or "expenses of sale". Some examples of these expenses include precommercial thinning and timber stand improvement costs, management costs (excluding the landowner's time), tree marking costs, equipment maintenance costs, etc. (For a more complete listing of what can be deducted, the landowner should consult a qualified tax expert or the Internal Revenue Service.)

This 16.3 percent IRR compares very favorably with alternate investments such as certificates of deposit and corporate bonds. The big disadvantage with most of these other forms of investment is that they do not have the tax benefits of forestry investments. Therefore, it can be seen that forestry investments can be quite lucrative-provided they are managed properly.

\section{References}

Kessler, George D.; Cody, Jack B. Forestry as an investment: how to compare planted pines to other investments. Clemson, SC: U.S. Department of Agriculture, Extension Service, Clemson University; 1980. 8 p.

Reynolds, R. R. Guide to the Crossett Experimental Forest. New Orleans, LA: U.S. Department of Agriculture, Forest Service, Southern Forest Experiment Station, $1951.65 \mathrm{p}$.

Gregory, G. Robinson. Forest resource economics. New York: The Ronald Press Company; 1972. 548 p. 


\section{Precommercial Thinning}

While much of the South's pine land suffers from too little stocking per acre, many thousands of acres suffer from too much stocking. Areas of natural pine reproduction can often develop into dense, overstocked stands. To stimulate growth of these overcrowded stands, precommercial thinning is usually recommended. Why? Because we know that overcrowding stunts tree growth. In one study at Crossett, the following observations were made 12 years after precommercial thinning of an 8-year-old natural loblolly pine stand:

-Average d.b.h. was 25 percent larger than on unthinned check plots

- Pulpwood yield was 4.5 cords per acre more than on unthinned check plots

- Total yield was 112 percent greater than on unthinned check plots

This demonstration area illustrates a tested precommercial thinning technique that could be used by private nonindustrial landowners in natural even-aged pine stands.

\section{History}

In this demonstration, a 10 -acre strip ( 330 X 1,320 feet) was originally clearcut and the site prepared in 1971 for the establishment of a progeny test. In 1972, pine seeded in from the adjacent pine stands, but the resulting reproduction was mowed in the fall of 1973. Due to budget constraints and other administrative problems, the progeny test was never established, and during 1974-75, the area again reseeded. In October 1979, an inventory of the area disclosed an average of 16,600 seedlings per acre.

\section{Treatments}

In October 1979, twelve 0.4 -acre plots were established and 6 were precommercially thinned. The remaining plots were left to serve as controls (fig. 18).

Mechanical strip-thinning, a proven precommercial thinning technique, was used throughout. Double passes were made in an east-west direction with a 6-foot-wide heavy duty rotary mower pulled by an industrial-size wheeled tractor. The results were 12-foot-wide swaths alternating with 1-foot-wide uncut strips (fig. 19).

\section{Results}

Precommercial thinning effectively reduced the stand from 16,600 stems per acre (fig. 18) to 1,900 stems (fig. 20), resulting in an 89 percent density reduction. Of the residual stems, 650 were less than 4.5 feet tall, 860 were between 5.0 and 9.5 feet in height, and the remaining 390 were over 9.5 feet tall. These 390 dominant and codominant stems will probably develop into future crop trees.

A time study showed that the pine stand was thinned at the rate of 1.5 acres per hour. Had the stand been thinned at a younger age, lighter weight equipment could have been used with consequent lower costs.

In January 1983, a biennial prescribed burning program was started for fuel hazard reduction on all 12 plots. Three additional 0.4 -acre plots were established 


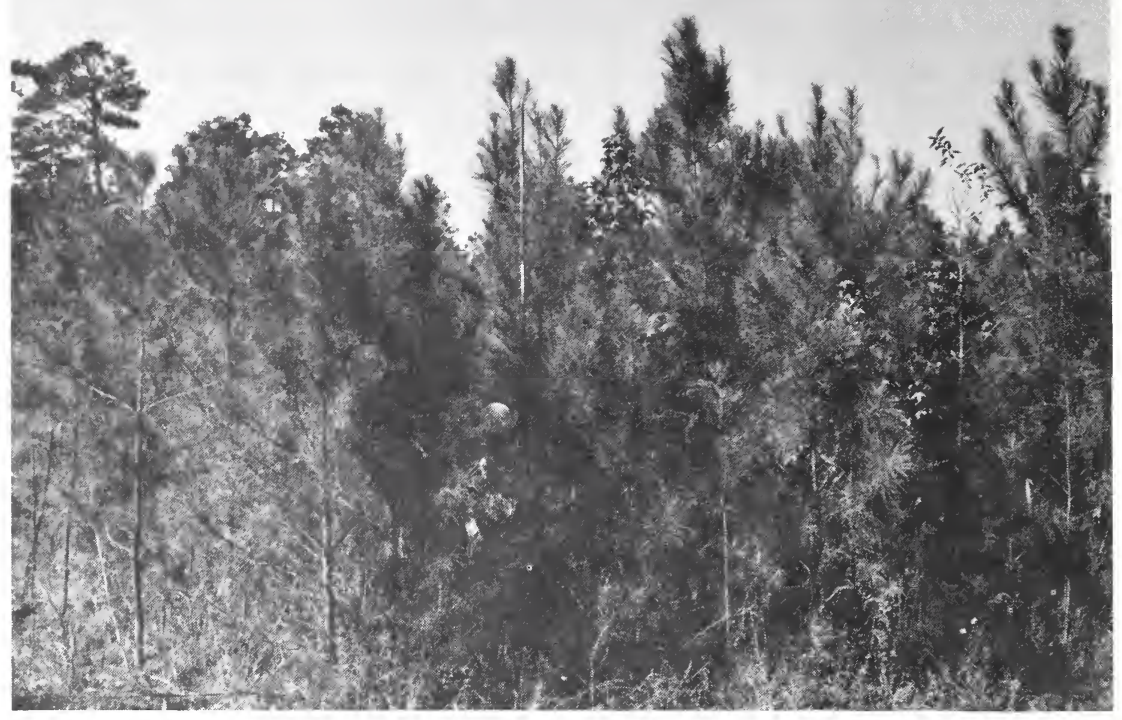

Figure 18. Unthinned 5- to 6-year-old natural pine stand with approximately 16,600 stems per acre.

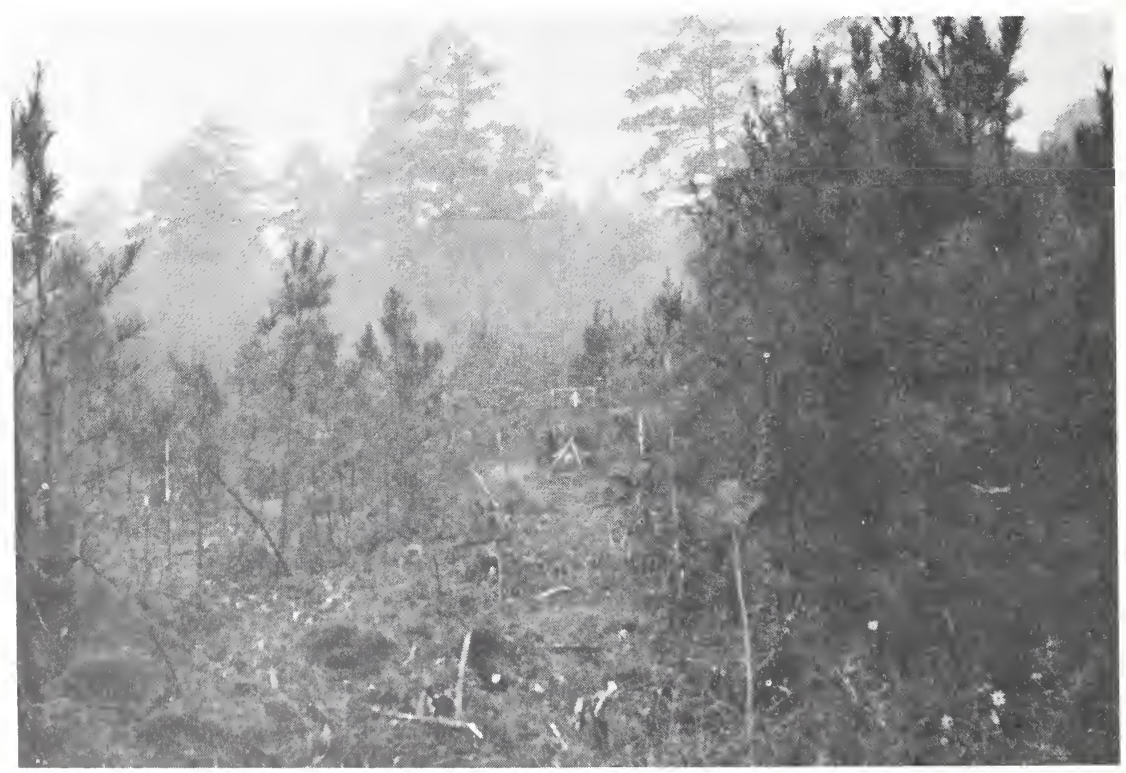

Figure 19. Precommercial thinning was accomplished by mowing 12-foot-wide swaths alternating with 1 -foot-wide uncut strips. 


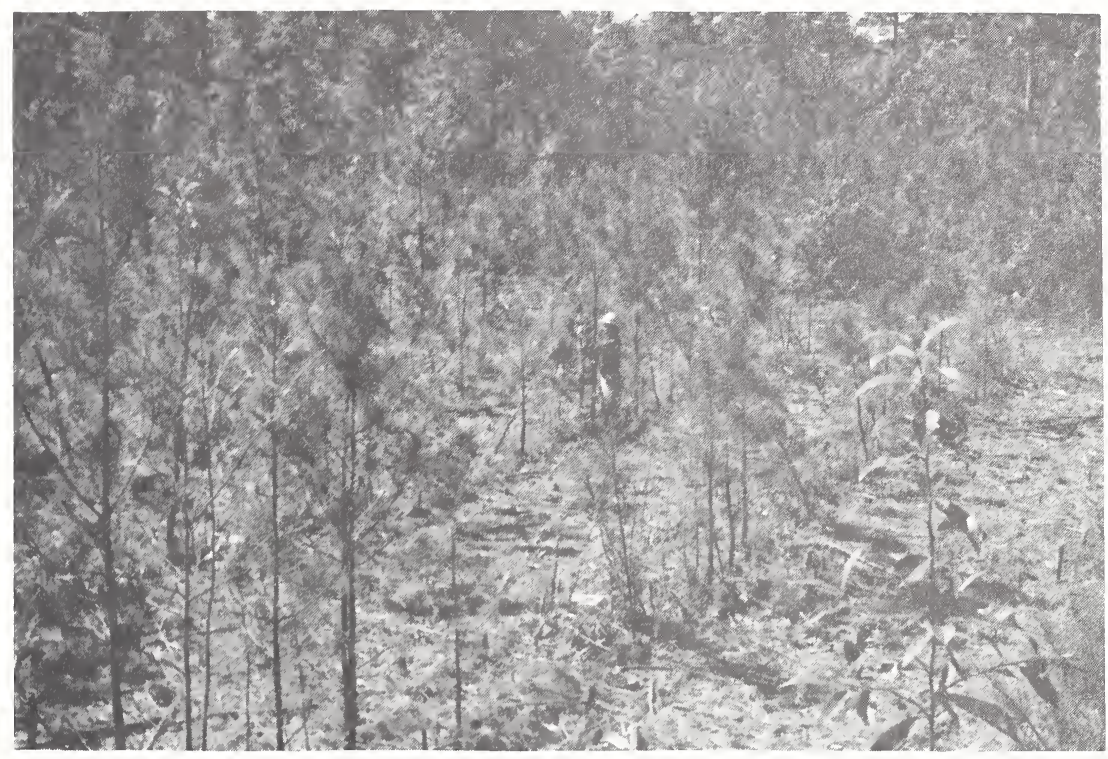

Figure 20. Precommercially thinned 5- to 6-year-old natural pine stand leaving approximately 1,900 stems per acre.

prior to burning and were retained as untreated controls. A second biennial burn was conducted in February 1985. Six growing seasons following precommercial thinning, dominant pines on thinned plots had average diameter above merchantable size (4-inch d.b.h. class); but average diameters of dominants on unthinned plots had not yet reached merchantability .

As a result of natural mortality and prescribed burning, pine density changed dramatically on unthinned plots. In the fall of 1985, respective densities were 1,900; 3,400; and 3,000 pines per acre on thinned/burned, unthinned/burned, and untreated control plots.

\section{Conclusions}

Does precommercial thinning pay for itself? That depends on when it is done. Cost, of course, depends on tree size and number of stems per acre; hence it's important to thin as early as possible. Costs can be very high in extra dense stands, but numerous research studies reveal that financial rewards can also be high. Precommercial thinning (combined with hardwood control at time of regeneration) has been found, in some cases, to increase financial returns by as much as four times those possible with no treatment. So the answer is that precommercial thinning can, indeed, more than pay for itself if the stand is thinned at an early age and costs are reasonable.

A properly done precommercial thinning in a severely overstocked stand can leave the stand looking decimated. Thus, the key to success is to thin early! Unfortunately, most precommercial thinning can be described as "too little, too late". 


\section{References}

Balmer W. E.; Utz K. A.; Langdon, O. G. Financial returns from cultural work in natural loblolly pine stands. South. J. Appl. For. 2(4): 111-117; 1978.

Balmer, W. E.; Williston, H. L. The need for precommercial thinning. Forest Management Bulletin. Atlanta, GA: U. S. Department of Agriculture, Forest Service, Southeastern Area, State and Private Forestry; 1973. 6 p.

Grano, C. X. Precommercial thinning of loblolly pine. Jour. For. 67:825-827; 1969. 


\section{Sudden Sawlogs}

Private, nonindustrial landowners often have abandoned agricultural farmland on their properties that they would like to convert to productive timberland. Unless a suitable seed source is available to provide natural regeneration, the landowner usually has to establish a plantation by planting seedlings or by direct seeding. Plantation establishment can require a sizable capital investment with no financial returns until the trees reach merchantable size. Under conventional management, this normally requires at least 15 to 20 years before pulpwood-size trees can be harvested and 40 to 50 years for sawtimber-size trees.

Research has developed plantation management techniques that provide good returns on forestry investments in a relatively short period of time. The demonstration described here illustrates some of these management alternatives.

\section{History}

During the winter of 1944-45, the Crossett Lumber Company handplanted loblolly pine on an abandoned cotton field at a 6 X 6 foot spacing (about 1,200 trees per acre). At plantation age 9 (1953), the U. S. Forest Service imposed four thinning treatments to determine whether a plantation on a good site ( site index $=90$ ) could be managed to produce good quality sawtimber on a short rotation by combining early thinning, understory vegetation control, and pruning. Of the treatments imposed, three were intensive and one was conventional. The conventional treatment was designed to simulate typical industrial management and to serve as a control for the three intensive treatments.

\section{Treatments}

When the thinning treatments were imposed, dominant and codominant trees on quarter-acre measurement plots averaged 4 inches d.b.h. and 22 feet in height. Survival was 91 percent, giving 1,100 stems per acre. Treatments were:

- Sawtimber Only-This stand was precommercially thinned to 100 crop trees per acre at age 9 (fig. 21). Three additional commercial thinnings (at ages 19, 24 , and 27) reduced the stand to 41 crop trees per acre at age 30 . Crop trees were pruned to half their total height after the first thinning and every 3 years afterwards until clear length averaged 33 feet at age 24 . Understory vegetation was controlled by mowing every 2 years, beginning at age 19 .

- Sawtimber + Pulpwood-At age 9, 100 crop trees were selected. Noncrop trees whose crowns were within 5 feet of crop trees were removed in a precommercial thinning at age 9, and in commercial thinnings at ages 12 and 15 . Two additional commercial thinnings (at ages 19 and 27) reduced the stand to 52 crop trees per acre at age 30. Crop trees were pruned and plots mowed as in the "Sawtimber Only" treatment.

- Delayed Sawtimber-This stand was commercially thinned to 100 crop trees per acre at age 12. Two additional commercial thinnings (at ages 24 and 27) reduced the stand to 45 crop trees per acre at age 30. Crop trees were pruned and plots mowed as in the "Sawtimber Only" treatment. 


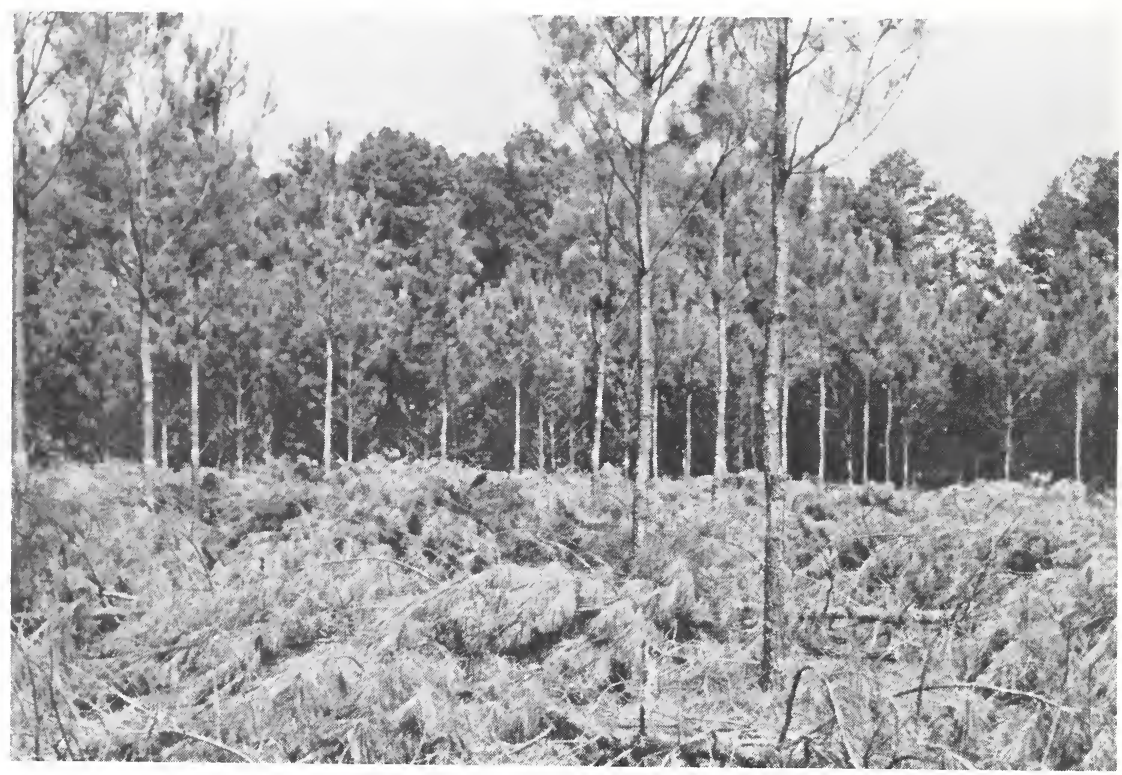

Figure 21. "Sawtimber Only" plot immediately following thinning to 100 trees per acre at plantation age 9 (1953). Trees averaged 4 inches d.b.h. and 22 feet in height.

- Conventional Management-At age 12, and at 3-year intervals therafter, the stand was commercially thinned from below to a residual basal area of 85 square feet. At age 30, 116 crop trees per acre remained. There was no pruning or mowing.

The purpose of the heavy thinning and understory control was to reduce competition for soil moisture and thereby accelerate growth of the crop trees. Artificial pruning was done to ensure obtaining two high quality sawlogs from each crop tree.

\section{Results}

The effects of the management treatments on total production are summarized in table 7. Production data in the table assume a clearcut of all plots at age 30 , thus total production represents standing volume at age 30 plus volume from intermediate commercial thinnings.

Table 7. Total production per acre by treatments through plantation age 30 (1974).

\begin{tabular}{lccccc} 
& & & \multicolumn{3}{c}{ Total production thru age 30} \\
\cline { 4 - 6 } Treatment & $\begin{array}{c}\text { Average } \\
\text { d.b.h. }\end{array}$ & $\begin{array}{c}\text { Trees } \\
\text { per acre }\end{array}$ & $\begin{array}{c}\text { Total } \\
\text { merch. }\end{array}$ & Sawlogs ${ }^{1}$ & Pulpwood \\
\hline & $($ In. $)$ & $($ No. $)$ & (Cu. ft.) & (Bd. ft.) & (Cords) \\
Sawtimber only & 17.0 & 41 & 2,976 & 9,900 & 14 \\
Sawtimber + pulpwood & 16.0 & 52 & 3,260 & 9,500 & 18 \\
Delayed sawtimber & 16.0 & 45 & 3,585 & 9,500 & 22 \\
Conventional & 11.2 & 116 & 4,678 & 3,200 & 46 \\
\hline
\end{tabular}

${ }^{1}$ Doyle scale. 
The purpose of the three intensive treatments was to produce sawlog-size trees in a relatively short time period, and they did just that. The intensive treatments produced crop trees averaging 16 to 17 inches d.b.h. by age 30. In terms of total production through age 30 , conventional management produced about 45 percent greater total cubic-foot volume (or 150 percent more pulpwood) than did the sawtimber treatments. However, the sawtimber plots produced about 200 percent greater sawlog volume than did conventional management. This is significant since, in most cases, private nonindustrial landowners can make more income from selling sawtimber than from selling pulpwood.

To better illustrate the profitability of treatments, table 8 provides compounded ( 7 percent) costs and returns and the internal rates of return (IRR), present net value (PNV), benefit/cost ratios, and annual equivalents for the four treatments using two prunings for treatments 1,2, and 3 (see Discussion and Conclusions).

The economic analyses indicate that, through plantation age 30 , the delayed sawtimber treatment provided the best financial investment and the conventional management treatment the poorest. However, based on the analyses, there were only small differences between all three intensive management treatments. Also, it should be noted that, if the rotation were lengthened to 40 or 50 years, the results of the financial analyses would change markedly, with the conventional management undoubtedly improving in investment ranking.

\section{Discussion and Conclusions}

So which management method is best? That depends on the objectives of the landowner. If the landowner wants to grow large sawlogs in the shortest possible time, and production of pulpwood is not an important consideration, the "sawtimber only" treatment is best. This produced the greatest board-foot volume and the largest average d.b.h. of any of the methods.

If the landowner's objective is to grow sawtimber-size trees combined with an early merchantable thinning of pulpwood, then the delayed sawtimber treatment is best. This was the only intensive treatment that provided a substantial early return from pulpwood thinnings that could offset pruning and understory treatment costs.

Table 8. Profitability of treatments in Sudden Sawlog study through plantation age 30 (1974).

\begin{tabular}{|c|c|c|c|c|c|c|}
\hline Treatment & Costs $^{1}$ & Returns $^{2}$ & IRR & $\mathrm{PNV}^{3}$ & $\begin{array}{c}\text { Benefit/ } \\
\text { cost } \\
\text { ratio }^{3}\end{array}$ & $\begin{array}{l}\text { Annual } \\
\text { equiv. }^{3}\end{array}$ \\
\hline & \multicolumn{5}{|c|}{ 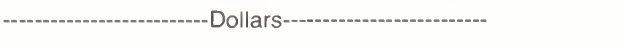 } & Dollars \\
\hline Sawtimber only & 1,227 & 1,936 & 9.3 & 93.15 & 1.578 & 7.51 \\
\hline Sawtimber + pulpwood & 1,202 & 1,903 & 9.4 & 92.03 & 1.583 & 7.42 \\
\hline Delayed sawtimber & 1,177 & 1,922 & 9.6 & 97.81 & 1.632 & 7.88 \\
\hline Conventional & 798 & 1,199 & 8.9 & 52.78 & 1.504 & 4.25 \\
\hline
\end{tabular}

${ }^{1}$ Costs were based on 1974 values compounded at 7 percent from time of application to 1974 .

${ }^{2}$ Returns were based on 1974 stumpage prices of $\$ 150 /$ Mbf (Doyle) and $\$ 10 /$ cd compounded at 7 percent from time of harvest to 1974 .

${ }^{3}$ Calculated at a 7 percent discount rate. 
All intensive treatments produced small sawlogs by age 21 ; however, it would benefit the landowner to carry these trees until age 30 , since the logs are larger later and would provide substantially more volume with the Doyle scale.

In retrospect, the intensive methods employed in the study could be improved and their costs reduced, thereby improving financial returns. An initial spacing of $6 \times 6$ feet is much too close if the objective is to grow sawtimber quickly. Other research studies have shown that spacings of $10 \times 10$ or $12 \times 12$ feet produce sawtimber sooner, and these wider spacings would reduce planting costs.

Selection of crop trees in this study was time consuming because many of the trees were forked due to tipmoth damage, or had stem galls caused by fusiform rust. Disease and insect problems are difficult to predict, but a spacing of $8 \times 10$ feet would provide more trees from which to select potential crop trees. A spacing of $8 \times$ 8 feet $(681$ trees per acre) or $8 \times 10$ feet ( 544 trees per acre) requires only about half as many seedlings as a $6 \times 6$ feet spacing $(1,210$ seedling per acre).

Heavy thinning is important. The first pulpwood thinning should occur about age 12. At this time, most of the trees removed should be of merchantable size. If thinning occurs much later than that, diameter growth will begin to slow down. Any submerchantable noncrop trees remaining after the first commercial thinning should be removed.

Pruning is still necessary if the objective is to produce high-quality, knotfree sawlogs, because trees planted at these wide spacings, followed by heavy thinning, will have numerous large limbs that would greatly affect wood quality. However, frequent light prunings to a height of 33 feet, as done in this study, are so costly that any potential profits could be nullified. If pruning is done to produce high-quality sawlogs, it should be done only once when the height of the selected crop trees is sufficient to leave 50 percent live crown ratio. Pruning should be confined to the first 17.3 feet of the stem because research has shown that about 42 percent of the total volume in a three-log loblolly pine is in the butt log. Likewise, pruning should be confined only to the best trees destined to form the final crop. If the objective is to maximize return on investment (generally the case for most landowners), it is doubtful that pruning can be justified. Since most loblolly pine sawlogs are used for framing, rough construction, plywood, or other products that command little or no premium if free from knots, pruning would be a waste of time and money. Therefore, in order to maximize returns, pruning should be done only when there is a sufficient premium to offset its costs.

In most loblolly stands, soil moisture is a limiting factor to tree growth. Competing understory vegetation robs crop trees of water needed to sustain maximum growth, especially during dry periods, so some form of understory vegetation control is necessary. Prescribed burning every 2 to 3 years would be easier and less expensive than mowing.

Under the proper conditions, "sudden sawlog" silviculture should produce sawlogs of sufficient quality in 30 years and also provide a good financial return on the investment. However, the landowner should employ all intensive cultural treatmentswide spacing, heavy thinning, and understory control-to insure maximum production. 
Also, it's best to remember that this type of management is recommended only for high quality sites (site index $=90$ or better at 50 years).

\section{References}

Burton, James D. Sawlogs in a pulpwood rotation. Forest Farmer 36(1): 8-20; 1976.

Burton, James D. Sawtimber by prescription-the sudden sawlogs story through age 33. Res. Pap. SO-179. New Orleans, LA: U.S. Department of Agriculture, Forest Service, Southern Forest Experiment Station; 1982. 9 p.

Burton, James D.; Shoulders, E. Fast grown, dense loblolly pine sawlogs: a reality. J. For. 72: 634-674; 1974.

Smith, D. M. The practice of silviculture. 7th ed. New York: John Wiley \& Sons, Inc.; 1962. p. 128-151.

Taylor, Fred W.; Burton, James D. Growth ring characteristics, specific gravity, and fiber length of rapidly grown loblolly pine. Wood and Fiber 14(3): 204-210; 1982.

Williston, Hamlin L. Pruning for better sawlogs. Southern Lumberman 227(2824): 129-130; 1973. 


\section{APPENDIX}

\section{Crossett Experimental Forest - General Information}

Climatic information:

Mean annual rainfall $=52$ inches

Growing-season precipitation

March - May = 16 inches

June - Aug. = 11 inches

Sept. - Nov. = 11 inches

Normal daily July temperatures

Minimum $=72$ Degrees $F$

Maximum $=93$ Degrees $F$

Average $=82$ Degrees $F$

Normal daily January temperatures

Minimum $=37$ Degrees $F$

Maximum $=58$ Degrees $F$

Average $=47$ Degrees $F$

Mean length of freeze-free period $=240$ days

Soils that occur on the Crossett Experimental Forest:

Site index

Series name

Classification

for loblolly'

Arkabutla silt loam

Aeric Fluvaquent

100

Bude silt loam

Glossaquic Fragiudalf

90

Providence silt loam

Typic Fragiudalf

85

' Site index is average height in feet of upper crown class trees at age 50 . 
Arkabutla soil is somewhat poorly drained and is found in the floodplain of streams. Bude soil is somewhat poorly drained and is found on stream terraces and uplands. Providence soil is moderately well drained and is found on uplands. Bude and Providence soils have a fragipan at 20 to 24 inches below the soil surface.

Major tree species growing on the Crossett Experimental Forest:

\begin{tabular}{ll} 
Common name & Scientific name \\
\cline { 2 - 2 } Loblolly pine & Pinus taeda \\
Shortleaf pine & P. echinata \\
Blackgum & Nyssa sylvatica \\
Sweetgum & Liguidambar styraciflua \\
Southern red oak & Quercus falcata \\
Cherrybark oak & Q. falcata var. pagodaefolia \\
Water oak & Q. nigra \\
Post oak & Q. stellata \\
White oak & Q. alba \\
White ash & Fraxinus americana \\
Mockernut hickory & Carya tomentosa \\
Bitternut hickory & C. cordiformis \\
Red maple & Acer rubrum \\
Flowering dogwood & Cornus florida \\
Winged elm & Ulmus alata
\end{tabular}

Loblolly pine usually accounts for about 70 percent of the pine component in predominantly pine stands. Red oaks, sweetgum, red maple, and flowering dogwood are normally the predominating broadleaf species in mixed pine-hardwood stands.

\section{Conversion To Metric Units}

$\begin{array}{lll}\text { Centimeters } & =\text { Inches } \times 2.54 \\ \text { Meters } & =\text { Feet } \times 0.3048 \\ \text { Kilograms } & =\text { Pounds } \times 0.454 \\ \text { Liters } & =\text { Gallons } \times 3.785 \\ \text { Cubic meters } & =\text { Cubic feet } \times 0.028 \\ \text { Hectares } & =\text { Acres } \times 0.405 \\ \text { Square meter per hectare } & =\text { Square feet per acre } \times 0.23 \\ \text { Cubic meters per hectare } & =\text { Cubic feet per acre } \times 0.07 \\ \text { Stems per hectare } & =\text { Stems per acre } \times 2.471\end{array}$




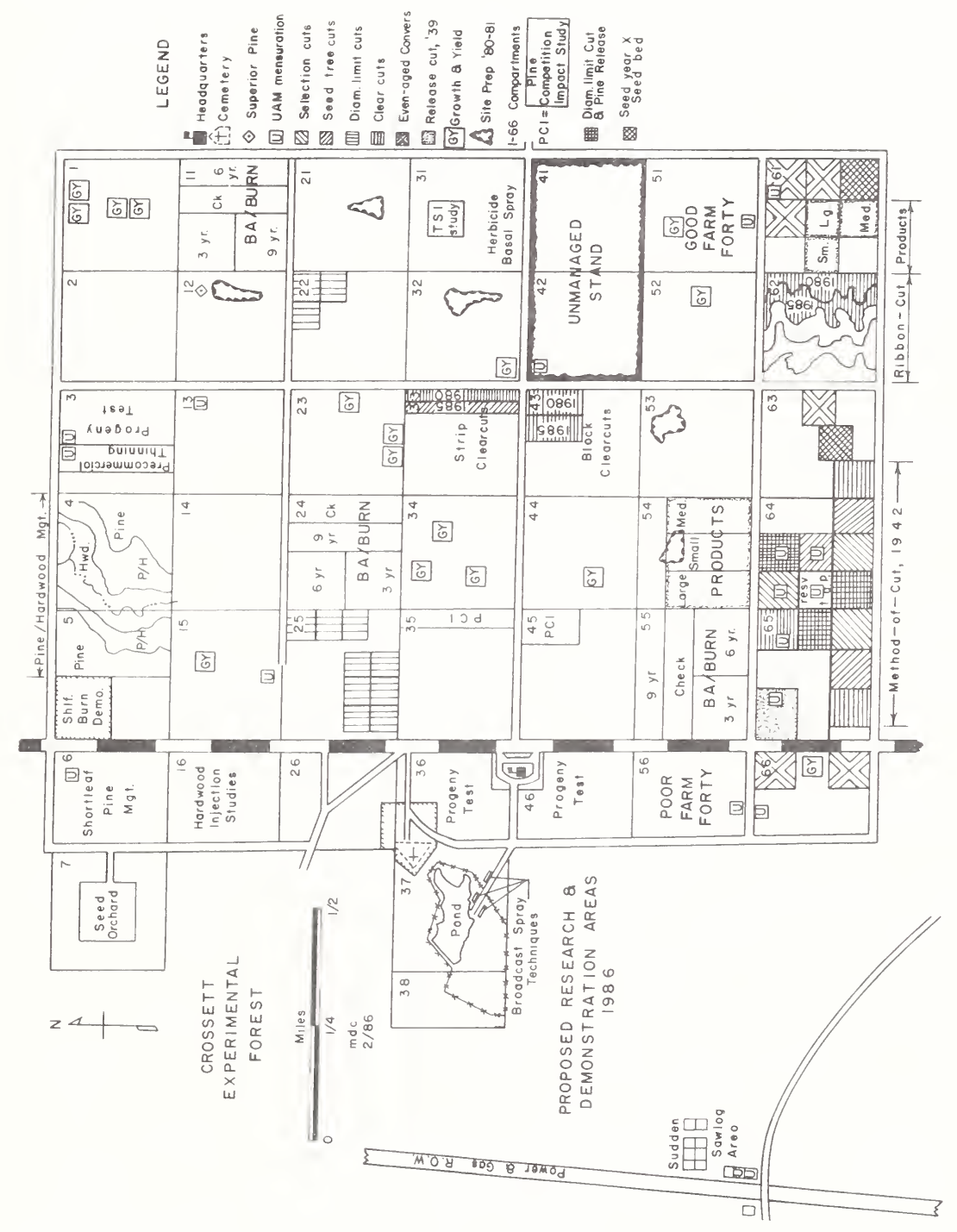

map of CEF 


\section{FORESTRY TERMINOLOGY}

Acre

All-aged or

Uneven-aged

Forest Management

All-aged or

Uneven-aged Stand

Allowable Cut

Artificial

Regeneration

Basal Area

Board Foot

Breast Height

Broadleaf

Canopy

Clearcut
An area of land containing 43,560 square feet. A square acre would be about 209 by 209 feet. A circular acre would have a radius of 117.75 feet.

Managing a forest by periodically removing individual trees or groups of trees from the stand while preserving its natural appearance (see "selection method" and "all-aged stand").

A forest stand with trees of different ages or sizes (cf. "evenaged").

The volume of wood that can be cut from a forest during a given period without exceeding the forest's net growth during that period.

Establishing a new forest by planting or direct seeding.

A measurement designating: (a) Of a tree - the cross-sectional area (in square feet) of the trunk at breast height ( 4.5 feet above the ground). For example, the basal area of a tree 14 inches in diameter at breast height is about 1 square foot. Basal area $=0.005454$ times diameter squared. $(b)$ of an acre of forest - the sum of basal areas of the individual trees on the area. For example, a well-stocked pine stand might contain 80 to 120 square feet of basal area per acre.

A unit of wood equaling 144 cubic inches. The term is commonly used to measure and express the amount of wood in trees, sawlogs, veneer logs, or lumber. Board feet in a piece of wood are determined by: (length in feet $X$ width in inches $\times$ thickness in inches) divided by 12 .

A measurement point taken 4.5 feet above ground level (see “D.b.h").

See "hardwoods".

The layer of tree crowns in a forest.

A harvesting and regeneration method that removes all the trees (regardless of size) on an area. Clearcutting is most commonly used with species like pine that require full sunlight to reproduce and grow well. Clearcutting produces an even-aged forest stand. 
Climax Forest

Commercial

Cut

Codominant

Cord

Crop Tree

Crown

Cubic Foot

Cull

Cutting Cycle

D.b.h.

Diameter

Diameter-Limit Cutting
The final stage of plant succession in which species composition remains relatively stable. The climax forest for most of Arkansas, for example, would be the oak-hickory forest type. Pine is an intermediate species preceding the climax forest.

A cut of a sufficient number (or volume) of trees of merchantable-size to make the harvesting operation economically feasible (see "Merchantable Timber").

Trees with medium-sized crowns forming the general level of the crown cover. They receive full light from above but are crowded on the sides and thus receive comparatively little side light.

A stack of round or split wood containing 128 cubic feet including wood, bark, and air space. A standard cord measures $4 \times 4 \times 8$ feet.

A tree identified to be grown to maturity and for final harvest cut. It is usually selected on the basis of its proximity to other trees and its quality and species.

The branches and foliage of a tree.

A wood volume measurement containing 1,728 cubic inches, such as would exist in a piece of wood measuring 1 foot on a side. A cubic foot of wood contains about 6 to 10 useable board feet of lumber rather than 12 board feet because some wood is lost as sawdust and shavings during processing.

A tree or $\log$ of merchantable size made useless for all but firewood because of shape, disease or insect damage, or injury.

The planned time interval between major harvesting operations in the same stand, usually in uneven-aged stands. For example, a cutting cycle of 10 years in a stand means a harvest cut every 10 years.

Abbreviation for tree diameter at breast height ( 4.5 feet above the ground). D.b.h. is usually measured in inches.

The length of a straight line passing through the center of a tree. Tree diameter is usually measured 4.5 feet above ground level (see "D.b.h." and "Breast Height”).

A selection method of harvesting whereby all merchantable trees above a specified diameter are harvested. In some cases minimum diameter may be the stump diameter. Unless all trees above the designated minimum diameter are cut, this cutting method could be a form of "high-grading" (see this term). 
Direct Seeding

Dominant Tree

Even-aged Forest

Even-aged Forest Management

F.I.P. (Forest Incentives

Program)

Firebreak or

Fire lane

Forest

Forest Management

Forest Management Plan

Forestry

Forty
A method of artificial regeneration whereby tree seeds are sown on the surface of a prepared site.

A tree having a crown that extends above the general level of the crown cover and receives full light from above and partly from the side; it is larger than the average trees in a stand, with well developed crown but possibly somewhat crowded on the sides.

A stand of trees that are about the same age (usually within 10 years). An even-aged forest may be a natural or an artificially regenerated stand (see these terms).

A forest management system that involves periodic harvesting of all trees on part of the forest at one time or in several cuttings over a short time with the objective of producing stands containing trees all the same or nearly the same age. This type of management is commonly applied to conifers and to some hardwoods.

A Federal cost-sharing program of the Agricultural Stabilization and Conservation Service (ASCS) that provides payment to landowners who complete certain approved forest management practices such as site preparation and planting.

A natural or manmade barrier usually created by the removal of brush, trees, leaves, and other vegetation. Used to prevent the spread of fire.

Informally, a plant community dominated by trees and woody plants. From a technical forest management standpoint, a collection of stands administered as a unit.

Informally, a long-term program of proper care to insure that the forest stays healthy and vigorous and provides the products and values the landowner desires. Technical definition: applying forestry principles and technology and business practices (such as accounting, benefit-cost analysis, etc.) to forest management.

Usually a written document that includes overall guidelines and recommended practices for current and future management to meet landowner objectives.

The science, art, and practice of managing and using trees, forests, and their associated resources for human benefit.

A land tract of 40 acres, usually $1 / 4$ mile square. 
Girdling

Group Selection

Growing Stock

Hardwoods

Harvest

Herbicides

High Grading

Improvement Cut

Increment Borer

Intermediate Cut

Intermediate Trees
Either a manmade cut or animal, insect, or disease damage that completely encircles the tree truck, going through the bark and cambium, and penetrating the sapwood. Girdling usually kills the tree by stopping the flow of nutrients between the roots and crown.

(see "Selection Method".)

All live trees (except rough and rotten trees) in a forest or stand, including sawtimber, poletimber, saplings, and seedlings.

A term describing broadleaf, usually deciduous, trees such as oaks, maples, ashes, elms, etc. The term does not necessarily refer to the hardness of the wood. Some hardwoods (such as live oak and American holly) are evergreen.

In general usage, removing some or all the trees on an area. Technical definition: Removing trees on an area to 1) generate income, 2) develop the environment necessary to regenerate the forest; and 3) on occasion, achieve some particular objective such as the development of special wildlife habitat needs.

Chemicals that kill plants.

The practice of removing only the biggest and best trees from a stand during a harvest operation and leaving only the poorest, lowest quality culls to dominate the site.

A type of intermediate cut with the primary objective to improve the remaining stand (see "TSI" and "Intermediate Cut").

A hollow augerlike instrument used to bore into the tree trunk to remove a wood core that shows the tree's growth rings.

Removing immature trees from the forest sometime between reproduction and maturity to improve the quality of the remaining stand. An intermediate cut may or may not generate income (see "Thinning").

Trees shorter than dominant and codominant trees but with crowns extending into the crown cover formed by the dominant and codominant trees. These trees receive little light from above and none from the sides. They usually have small crowns considerably crowded on the sides.

(a) A piece of the woody stem (trunk or limb) of a tree.

(b) The trunk portion of a tree.

(c) A tree section exactly 16.3 feet in length, including trim allowance. 
Log Rule

Mature Tree

Mbf

Merchantable Timber

Mortality

Multiple Use

Natural Stand

Old Growth

Overtopped Trees

Plantation

Precommercial

Thinning

Prescribed Burn (or Fire)

Prescription, Stand
A table of values that gives estimated board foot contents for logs of various diameters and lengths. The three log rules most used in the U.S. are the International 1/4-inch, Scribner, and Doyle. The Doyle Rule is the most commonly used rule in the South and is the legal rule in many southern States, including Arkansas.

A tree that has reached the desired size or age for its intended use. These factors will vary considerably depending on the species and intended use.

Abbreviation for thousand board feet. A unit of measure for tree volume or sawed lumber.

A stand in which trees are of sufficient size and volume per acre to provide a commercial cut (see this term).

The number of (or volume of) growing stock trees dying from natural causes during a certain time period.

Land management for more than one purpose, such as wood production, water, wildlife, recreation, forage, esthetics, or clean air.

A stand of trees resulting from natural seedfall or sprouting.

Commonly, a mature or overmature forest that is essentially uninfluenced by human activity (see "Second Growth").

Suppressed trees with crowns entirely below the general level of the crown cover, which receive no direct light either from above or from the sides.

An artifically forested area established by planting or direct seeding. It is usually made up of a single species.

Cutting in a submerchantable-size stand (the cut trees are too small to be sold for forest products) to increase growth rate of residual trees (see "Thinning").

The controlled use of fire to achieve forest management objectives. Prescribed fire can be used to reduce hazardous fuel levels, control unwanted vegetation, improve visibility, and improve wildlife habitat.

Usually a document written by a forester prescribing present and future treatments for a forest stand (smallest unit of management) aimed at accomplishing certain forest management objectives and long-term goals. 
Pruning

Pulpwood

Reforestation

Regeneration

Regeneration Cut

Release Cutting

Reproduction

Rotation

Salvage Cut

Sanitation Cut

Sapling

Sawlog

Sawtimber Stand

Second Growth
Can be of two types: Artificial pruning refers to removing live or dead branches from standing trees. With forest trees, pruning is generally done along the trunk to remove the side branches which cause knots in the wood. Some natural selfpruning occurs as lower limbs are shaded out by the forest canopy.

Wood cut primarily to be converted into woodpulp for the manufacture of paper, fiberboard, or other wood fiber products. Pulpwood-size trees are usually a minimum of 4 inches d.b.h.

Reestablishing a forest by planting or seeding an area where forest vegetation has been removed.

See reproduction.

A cutting operation to remove the old trees and leave environmental conditions favorable for establishment of reproduction.

A cutting made to regulate the species composition and improve the quality of very young stands.

(a) Young trees that will grow to become the older trees of the future forest. (b) The process of forest replacement or renewal. This may be done artificially by planting seedlings or seed or naturally by sprouting or natural seeding.

The number of years required to establish and grow trees to a specified size, product objective, or condition of maturity.

Harvesting dead trees or those in danger of being killed by natural causes (insect, disease, flooding, etc.,) to save their economic value.

Harvesting or killing trees infected or highly susceptible to insects or diseases to protect the rest of the forest stand.

A small tree, usually between 2 and 4 inches d.b.h.

A log large enough to be sawed into lumber, usually at least 10 to 12 inches in diameter.

A group of trees that includes individual trees large enough to be sawed into lumber.

Forests that reproduce naturally after removal of the original forest by cutting, fire, or other cause (see "Old Growth"). 
Seedling

Seedtree

Method

Seed Year

Selection Method

Shade Tolerance

Shelterwood

Harvest

Silviculture

Site

Site Index

Site Preparation

Softwoods

Soil Texture (a) A tree, usually less than 2 inches in d.b.h., that has grown from a seed. (b) A nursery-grown tree that has not been lifted and replanted in the nursery.

Removing all trees from the harvest area at one time except for a few scattered trees left to provide seed to establish a new forest stand.

A year in which a given species generates (over a considerable area) a large seed production.

Harvesting individual trees or small groups of trees at periodic intervals (usually 5 to 15 years) based on their physical condition or degree of maturity. This produces an uneven-aged stand. Trees selected are usually marked and tallied.

A tree's capacity to develop and grow in the shade of, and in competition with, other trees.

Removing trees on the harvest area in a series of two or more cuttings so that new seedlings can become established from the seed of older trees. This method produces and even-aged forest.

The art, science, and practice of establishing, tending, and reproducing forest stands of desired characteristics based on knowledge of species traits and environmental requirements.

(a) A tract of land with reasonably uniform soil and climatic conditions. (b) An area with the capacity to produce a particular forest or other vegetation because of biological, climatic, and soil factors.

A measure of forest site quality based on the height (in feet) of the dominant trees at a specified age (usually 50 years for natural stands and 25 for planted stands). A site index of 95 means that the expected height of the dominant trees at an index age of 50 years would be 95 feet on a particular area of land.

Preparing an area of land for planting, direct seeding, or natural reproduction by clearing, chemical vegetation control, burning, disking, bedding, windrowing, or raking.

A term describing trees belonging to the order Coniferales, usually evergreen, conebearing, and with needles or scalelike leaves such as pines, spruces, firs, and cedars, often called "softwood." Baldcypress is a deciduous conifer (cf. "Hardwoods").

The "feel" or composition of a soil based on the proportion of sand, silt, and clay in the soil. 
Stands, Timber

Stocking

Stumpage

Succession

Suppressed Tree

Sustained Yield

Thinning

Timber

Timber Marking (a) Fully stocked. A forest stand with all the growing space effectively occupied but having ample room for the developing crop trees. (b) Overstocked. Overcrowding in a stand leading to retarded growth. (c) Understocked. A stand with the growing space not effectively occupied by crop trees. (d) Mixed stand. A stand having less than 80 percent of the trees of a single species in the main crown canopy. (e) Pure stand. A stand with at least 80 percent of the trees of a single species in the main crown canopy. (f) Poletimber stand. A stand with most trees from 5 to 10 inches in diameter. (g) Sawtimber stand. A stand with most trees large enough in diameter (usually 10 to 12 inches d.b.h. or larger) to be sawed into lumber. (h) Residual stand. The stand remaining after cutting. (i) Old field stand. A stand on land once used for agricultural crops or for pasture.

The number of trees in a forest stand. Stocking level is often described in terms of the desirable number of trees for best growth and management, such as partially stocked, well stocked, or overstocked.

The value or volume of a tree or group of trees as they stand in the woods uncut ("on-the-stump").

The replacement of one plant community by another until ecological stability (climax forest) is achieved. For example, an abandoned farm, if left to nature, would gradually go through different stages of vegetative cover and finally reach the climax forest stage after 100 or more years (see "Climax Forest").

\section{(see "Overtopped Trees".)}

Management of forest land to produce a relatively constant amount of timber and/or revenue.

Generally, a harvest cutting in an immature stand to reduce the number of trees per acre. Hopefully, the remaining trees will grow faster and produce higher quality wood.

(a) Growing trees capable of being used for wood products.

(b) A large, dressed piece of lumber used in forming part of a structure, such as bridge timber.

The process of designating trees to be cut or trees not to be cut, usually by spraying a spot with brightly colored paint at the base of the tree and another at eye level. 
Tract

Tree Species

TSI (Timber

Stand Improvement)

Tree

Tree Farm

Tree Injectors

Uneven-aged

Forest

Uneven-aged

Forest Management

Volume Table

Wolf Tree
A parcel of land considered separately from adjoining land because of differences in ownership, timber type, management objective, or other characteristics.

A group of related trees having common characteristics, capable of interbreeding and biologically classified in the same category. Loblolly pine and slash pine are the common names of two different species.

Improving the quality of a forest stand by removing cull trees and brush, leaving a stand of good quality trees. Cull trees may be removed by chemicals, fire, girdling, or cutting.

A woody plant having a well-defined stem and a more or less definitely formed crown, usually attaining a height of at least 8 feet.

A privately owned forest (woodland) in which the production of timber crops is a major management goal. Additionally, a woodland may be specifically recognized as a "Tree Farm" by the American Tree Farm System, an organization sponsored by the American Forest Institute, Washington, DC.

Tools or equipment specially designed to inject chemicals into a tree trunk. Most common injectors can be hand operated.

A forest with many ages of trees present (technically, more than two age classes) plus considerable difference in the ages.

See all-aged forest management (cf. "Even-aged Forest management").

A table estimating the volume of wood in a standing tree based on the tree's measurements (most commonly d.b.h. and merchantable height).

A tree that is taking up more space than its value would warrant (usually an old, large, low quality tree with a wide spreading crown). 
The use of trade, firm, or corporation names in this guide is for the information and convenience of the reader. Such use does not constitute an official endorsement or approval by the U.S. Department of Agriculture of any products or service to the exclusion of others that may be suitable.

This guide reports research involving herbicides. It does not contain recommendations for their use, nor does it imply that the uses discussed here have been registered. All uses of herbicides must be registered by appropriate State and/or Federal agencies before they can be recommended.

CAUTION: Herbicides can be injurious to humans, domestic animals, desirable plants, and fish or other wildlife if they are not handled or applied properly. Use all herbicides selectively and carefully. Follow recommended practices for the disposal of surplus herbicides and their containers. 


